\title{
Geochemical and isotopic disequilibrium in crustal melting: An insight from the anatectic granitoids from Toledo, Spain
}

\author{
L. Barbero 1.2 and C. Villaseca \\ Departamento de Petrología y Geoquímica, Facultad de Ciencias Geológicas, Universidad Complutense, Madrid, Spain
}

\section{G. Rogers}

Isotope Geosciences Unit, Scottish Universities Research and Reactor Centre, Glasgow, Scotlalnd

\section{P. E. Brown}

Department of Geography and Geology, Division of Geology, University of St Andrews, St Andrews, Scotland

\begin{abstract}
In the Hercynian Anatectic Complex of Toledo (ACT) the anatectic granitoids include leucogranitic leucosomes, leucogranitic massifs, and restite-rich granites. They show a broad range of initial Sr and $\mathrm{Nd}$ isotope ratios from 0.711 to 0.720 and 0.51164 to 0.51203 , respectively, which clearly indicate the absence of isotopic homogenization in the melts. Broadly, the ranges reflect the isotopic variation of the metapelitic protoliths. If crustal melting occurs under water-undersaturated conditions, as is the case of the ACT, the generated melts do not isotopically and chemically equilibrate with the granulitic residuum. The preservation of heterogeneities could arise through a number of processes. (1) duration of the process:in which the presence of melts with disequilibrium features, and the high solid content of several of the granites in the ACT point to a very short-lived magmatic system, (2) limited diffusion in which poorly segregated and volatile undersaturated granitoids have a very restricted opportunity for isotopic and chemical homogenization, and (3) magma dynamics in which the low melting rates, the high restite and low water contents, and the silica-rich composition of these granites, together with the small volume and high viscosity values of the melts, seriously restrict the physical processes leading to homogenization.
\end{abstract}

\section{Introduction}

It is generally recognized that the radiogenic parent/daughter elemental ratios are often changed on a regional scale during high-grade metamorphism. As a result, isotopic systems are strongly disturbed, and the premetamorphic history of granulite facies terrains may be poorly constrained [Faure, 1986; Cherniak and Ryerson, 1993] Rb/Sr and $\mathrm{U} / \mathrm{Pb}$ ratios often decrease during high-T events, whereas the Sm-Nd system is considered to be less affected because of the relative immobility of these two elements under such conditions. The scale of the isotopic heterogeneities developed during such events is widely variable. Several works have documented high-grade regions in which the $\mathrm{Rb}-\mathrm{Sr}$ and $\mathrm{Sm}-\mathrm{Nd}$ systems are almost totally reset as a result of a high-T event. Bickle et al. [1988] described significant $\mathrm{Sr}$ isotopic homogenization in large volumes of crust during high-T regional metamorphism and crustal anatexis in the Trois Seigneurs massif (France), which they attributed to pervasive

\footnotetext{
${ }^{1}$ Now at Isotope Geosciences Unit, Scottish Universities Research and Reactor Centre, Glasgow, Scotland.

${ }^{2}$ Also at Department of Geography and Geology, Division of Geology, University of St. Andrews, St. Andrews, Scotland.

Copyright 1995 by the American Geophysical Union.

Paper number 95JB00036.

0148-0227/95/95JB-00036\$05.00
}

interaction with hydrothernal fluids. Peucat [1986] described whole rock homogenization of $\mathrm{Sr}$ isotopes in the anatectic granites from the St. Malo massif, where the associated metatexites and diatexites from which the anatectic granites were derived, remain highly heterogeneous. Nevertheless, the majority of anatectic granites generated during crustal melting events are isotopically heterogeneous. Deniel et al. [1987)] found a large isotopic variation, even on a meter scale, in the Manaslu leucogranite, which was interpreted not as a result of perturbation by fluids, but as reflecting isotopic heterogeneities in the source material. These data indicated that original heterogeneities in the source material had not been erased by melting, convection, or other magmatic processes.

It is important to note that the majority of granitic plutons which have been mobilized from their sources and emplaced at higher crustal levels exhibit a more constant isotopic composition on at large scale. In the Anatectic Complex of Toledo (ACT), part of the Hercynian orogen in Spain, we have found significant isotopic heterogeneity from a meter to a mineral scale in the metamorphic rocks and premetamorphic peak granitoids and in the anatectic granites, which include cordierite/gamet-bearing leucogranites and restite-rich types.

The main purpose of this work is to present $\mathrm{Sr}-\mathrm{Nd}$ isotopic data from the high-grade metamorphic rocks and anatectic granitoids of the ACT and to evaluate the importance of several factors which may lead to isotopic heterogeneity at deep crustal levels in contrast with the more widespread homogeneity shown by epizonal plutons. 


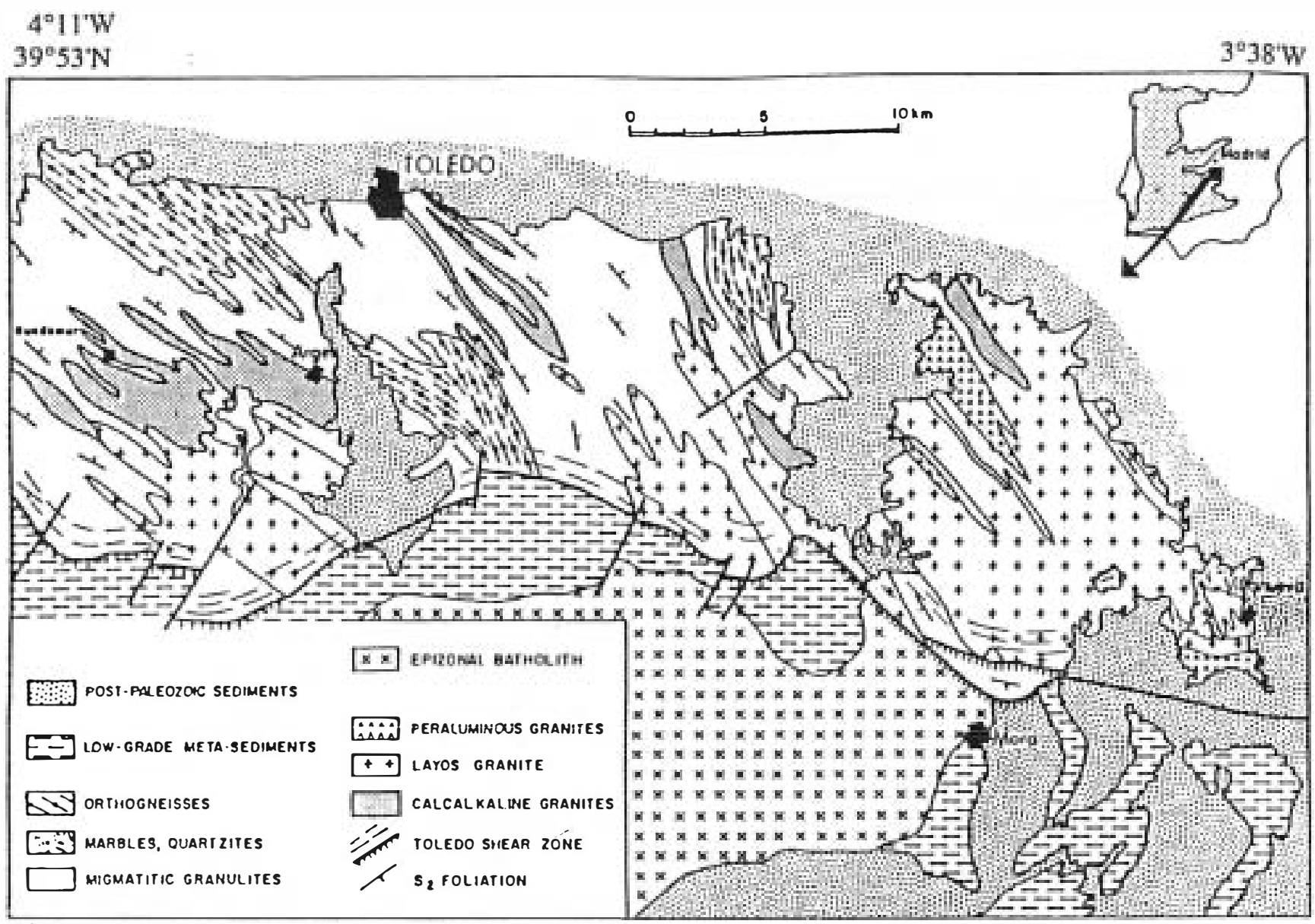

$39^{\circ} 36^{\prime} \mathrm{N}$

Figure 1. Geological map of the Anatectic Complex of Toledo (ACT). Inset map shows the location of the ACT in the Hercynian Belt of Iberia [Barbero, 1995]; (reproduced with the permission of the Geological Society, London).

\section{Geological Setting}

The Anatectic Complex of Toledo (ACT) is part of the Central Iberian Zone of the Hercynian orogen (Figure 1). It is bounded on the northern side by Alpine brittle fracture zones which separate it from the Tajo Basin which is filled with Cenozoic sediments. The southern margin consists of a ductile listric fault which juxtaposes Precambrian greenschist facies metasediments intruded by a late Hercynian epizonal pluton against the ACT [Barbero, 1995].

Three main groups of rocks can be distinguished in the ACT.

\section{High-Grade Metamorphic Rocks}

These comprise both metasedimentary and metaigneous types. The metasedimentary types include granulitic migmatites of pelitic composition, semipelites, minor quartzites, marbles, calcsilicate rocks, and conglomerates. The metasedimentary sequence of the ACT is Precambrian in age, although their absolute age is not well constrained [San José et al., 1990)] A detailed petrographic and mineralogical description of the granulitic migmatites, which are the most abundant metasedimentary type of the area, is given by Barbero [1995]. The granulitic migmatites exhibit a stromatic banded structure. Mesosomes have a nonfoliated, granoblastic texture and are mainly composed of cordierite, sillimanite, and garnet with minor biotite, plagioclase, and ilmenite. Mafic selvedges are always absent. Biotite and plagioclase are very scarce which seems to indicate that biotite dehydration melting reactions had almost run to completion. Leucosomes exhibit a variable width from $1-5 \mathrm{~cm}$ to $>10 \mathrm{~cm}$ and are mainly composed of $\mathrm{K}$-feldspar and quartz, with minor amounts of plagioclase. The presence of large, rounded garnet porphyroblasts is very characteristic, and they may also commonly contain cordierite prisms. The occurrence of garnet and cordierite may be explained as a result of crossing the biotite dehydration incongruent melting reaction.

\section{Premetamorphic Peak Granitoids}

Within this group it is possible to distinguish two types: (1) granites of calc-alkaline affinity with associated minor basic rocks (Argés granites and La Bastida and Toledo type gabbros) and (2) strongly peraluminous granites (Moncloa type).

The Argés granites comprise amphibole-bearing quartz dioritic to porphyritic monzogranitic varieties, typically with microgranular enclaves [Barbero et al., 1990] Abundant aluminous accessory phases such as gamet or cordierite are present which are probably the result of metamorphic growth during the thermal peak as indicated by their textures and compositions [Barbero et al., 1990; Barbero ,1992, 1995].

Moncloa type granite that also predates the thermal peak is strongly peraluminous gamet/cordierite-bearing granite with a coarse-grained texture and characteristic large (up to $15 \mathrm{~cm}$ ) K- 
feldspar phenocrysts. No microgranular enclaves have been found in this granite, the only enclave types being scarce metamorphic xenoliths.

\section{Anatectic Granites}

This group includes gamet/cordierite-bearing leucogranites (Cervatos leucogranites) and restite-rich granitoids (Layos granite).

The Cervatos leucogranites crop out as banded, elongated massifs, in most cases intimately associated with the Layos granites with which synplutonic emplacement structures are usually found. Two main types of leucogranites may be distinguished: (1) veinlike concordant sheets, usually of a meter scale in thickness interbanded or alternating with all the lithologies of the area. and (2) large, tabular bodies, up to $50 \mathrm{~m}$ in thickness, as, for example, in the Cervatos massif. Geochemical and petrogenetic aspects of these leucogranites will be discussed throughout the paper.

The Layos granite is a restite-rich type characterized by a high modal proportion of cordierite (up to $30 \%$ ). It also forms sheeted complexes generally interbanded with Cervatos leucogranites. Nevertheless, in several places there are kilometer-sized outcrops of these granites that are considered to be superposed sheets of similar restite-rich granites. A petrographic, mineralogical, geochemical, and petrogenetic discussion of these granites is given by Barbero and Villaseca [1992)] They proposed a restiteunmixing model to explain the mineralogy and chemical variability, in which the restitic end-member was represented by the granulitic migmatites of the area, and the liquid end-member by the Cervatos leucogranites.

\section{Metamorphic Grade}

The conditions of the metamorphic climax of the area have been estimated on the basis of the paragenesis of the granulitic migmatites and synorogenic granitoids. No clear evidence of the prethermal peak history is recorded in the area. Nevertheless, scarce textural evidence indicates that a significant part of the P$T$ path was in the sillimanite stability field before the reactions leading to the production of melts were crossed. A maximum pressure estimate of $800-1000 \mathrm{MPa}$ is obtained from the intersection of the biotite dehydration melting reaction with the Sil/Ky boundary [Barbero, 1995] There is a temperature maximum given by the absence of orthopyroxene in the metapelitic rocks, and it is also evident that the reaction

$$
\mathrm{Bt}+\mathrm{Sil}+\mathrm{Q}+\mathrm{Plg}=\mathrm{Gt}+/-\mathrm{Crd}+\mathrm{Melt}
$$

has been overstepped in these rocks. These facts point to temperatures of at least $800^{\circ} \mathrm{C}$. The results of several thermobarometric calculations give temperatures around 800 $850^{\circ} \mathrm{C}$ and pressures of $400-600 \mathrm{MPa}$ that are consistent with the established petrographic relations [Barbero, 1992, 1995]. This high-T/low-P metamorphism is more extreme than in other nearby Hercynian areas (Sierra de Guadarrama) [Villaseca et al., 1993] and can be related to the ascent of mantle-derived magmas in an orogenic extensional environment probably due to gravitational collapse of previously thickened crust. Partial melting is synchronous with this extension, leading to the generation of synkinematic granites.

\section{Age of the Metamorphic Climax}

The exact timing of the Hercynian metamorphism is not well constrained; constraints may be made by correlation with other areas and by indirect methods because no precise geochronological data are available. It is assumed that the hiatus in the stratigraphical record during the middle Devonian (390 Ma) marks the beginning of orogenesis, whereas the intrusion of discordant late plutons around 320-325 Ma [Villaseca et al., 1993] constraints the upper limit of the tangential tectonics and metamorphic recrystallisation in the area [Serrano Pinto et al., 1987]. Zircon ages of 370-380 Ma obtained from the Sierra de Guadarrama which are assumed to reflect the first Hercynian compressive event (D1-D2) [Wildberg et al., 1989] are consistent with these inferences.

$\mathrm{Rb}-\mathrm{Sr}$ geochronology of the ACT materials is problematic due to their highly heterogeneous character. Only the Cervatos leucogranites give a crude Hercynian "age" of $388 \pm 71 \mathrm{Ma}$. A Sm-Nd garnet-whole rock isochron derived from the Argés granites gives an age of $341 \pm 8 \mathrm{Ma}$ which is within error of a $342 \pm 7 \mathrm{Ma} \mathrm{K}$-Ar homblende age given from orthoamphibolites from the Sierra de Guadarrama (P. Ferreira, personal communication, 1986) which is considered to date the metamorphic climax in this area.

\section{Analytical Methods}

Between 8 and $15 \mathrm{~kg}$ of fresh rock sample were collected for chemical analysis. Major and trace elements were measured at Universidad Complutense de Madrid (Spain). Samples were dissolved using a mixture of $\mathrm{HF}$ and $\mathrm{HClO}_{3}$ in platinum crucibles. Major elements were determined by inductively coupled plasma - atomic emission spectrometry (ICP-AES) techniques using a Jovin-Yvon 38 spectrometer. Trace elements were measured by XRF in a Phillips PW1510 spectrometer. Around half of the samples were duplicated for major and trace elements by ICP-AES at Centre National de la Recherche Scintifique (CNRS) (Nancy, France) giving consistent results. Rare earth elements (REE) were measured by ICP-AES at CNRS (Nancy, France) following the method of Govindaraju and Nevelle [1987].

Isotopic determinations were performed at the Isotope Geosciences Unit of the Scottish Universities Research and Reactor Centre, East Kilbride, Scotland. Between 0.100 to 0.200 $\mathrm{g}$ of sample was dissolved using a mixture of $\mathrm{HF}$ and $\mathrm{HNO}_{3}$ in PFA teflon screw-top beakers (Savillex ${ }^{\star}$ ). Sm and $\mathrm{Nd}$ concentrations were determined by isotope dilution using ${ }^{145} \mathrm{Nd}$ and ${ }^{149} \mathrm{Sm}$ spikes. Sr and the REE were separated using standard cation exchange chromatography techniques. Sm and Nd were isolated from $\mathrm{Ba}$ and the other REE using three anion exchange columns, similar to the procedure outlined by O'Nions et al. [1977]. The first column separated $\mathrm{Ba}$ from the REE using a solution of $90 \% \mathrm{CH}_{3} \mathrm{COOH}-10 \% 5 \mathrm{M} \mathrm{HNO}_{3}$ as an eluent; the REEs were collected with $0.05 \mathrm{M} \mathrm{HNO}_{3}$. Sm and $\mathrm{Nd}$ were separated from each other on a temperature-controlled anion exchange column using a $\mathrm{CH}_{3} \mathrm{OH}-\mathrm{CH}_{3} \mathrm{COOH}-\mathrm{H}_{2} \mathrm{O}-5 \mathrm{M}$ $\mathrm{HNO}_{3}$ cocktail. The final $\mathrm{Ba}$ clean-up again involved the $\mathrm{CH}_{3} \mathrm{COOH}-\mathrm{HNO}_{3}$ procedure. Sm and Nd blanks were less than $0.1 \mathrm{ng}$. Sr samples were run on a single collector VG 54E thermal ionization mass spectrometer. The ${ }^{87} \mathrm{Sr} /{ }^{86} \mathrm{Sr}$ ratio was corrected for mass fractionation using ${ }^{86} \mathrm{Sr} /{ }^{88} \mathrm{Sr}=0.1194$. Repeat analysis of NBS $987 \mathrm{Sr}$ standard gave ${ }^{87} \mathrm{Sr} /{ }^{86} \mathrm{Sr}=0.71023 \pm 4$ (2 s.d., $n=30$ ) and are dominated by uncertainties in the $\mathrm{Rb} / \mathrm{Sr}$ ratios $(0.1 \%)$. Nd isotope ratio analyses were performed on a VG Sector 54-30 thermal ionisation mass spectrometer: data were acquired in multidynamic mode (to avoid intercollector gain calibration uncertainties) using a five collector peak jumping routine. The ${ }^{143} \mathrm{Nd} /{ }^{144} \mathrm{Nd}$ ratios were corrected for mass fractionation using 
${ }^{146} \mathrm{Nd} /{ }^{144} \mathrm{Nd}=0.7219$. During the course of this study the Johnson and Matthey $\mathrm{Nd}$ standard gave ${ }^{143} \mathrm{Nd} /{ }^{144} \mathrm{Nd}=0.511500 \pm$ 10 (2 s.d., $n=35$ ). $\mathrm{Sm}$ and $\mathrm{Nd}$ isotope dilution analyses were performed on the same mass spectrometer in static mode. Measured $\mathrm{Sm} / \mathrm{Nd}$ ratios are considered to be better than $0.15 \%$ (2 s.d.). The $\varepsilon_{\mathrm{Nd}}$ values were calculated using the following bulk earth parameters: ${ }^{143} \mathrm{Nd} /{ }^{144} \mathrm{Nd}=0.512638$ and ${ }^{147} \mathrm{Sm} /{ }^{144} \mathrm{Nd}=$ 0.1967 . The 2 s.d. error on $\varepsilon_{N d}$ values is \pm 0.4 .

\section{Major and Trace Element Geochemistry}

\section{Metapelitic granulitic migmatites}

We have analyzed three adjacent leucosome-mesosome pairs of granulitic migmatites (Table 1). The three studied mesosomes show similar compositions. They are strongly peraluminous with high concentrations of $\mathrm{Fe}_{2} \mathrm{O}_{3} \mathrm{t}$ and $\mathrm{TiO}_{2}$; low contents of $\mathrm{CaO}$ and $\mathrm{Na}_{2} \mathrm{O}$ and high $\mathrm{K}_{2} \mathrm{O}$ are typical of metapelitic materials. Trace metals such as $\mathrm{Cr}, \mathrm{Ni}, \mathrm{Sc}, \mathrm{V}$, and $\mathrm{Cc}$ show relatively high concentrations in accord with the high $\mathrm{Fe}$ and $\mathrm{Ti}$ contents. The large ion lithophile elements (LILE) have high contents when compared with to North American Shale Composite (NASC) [Gromet et al., 1984]. Zr contents of around 230 ppm (Table 1) are typical of metapelitic materials [Gromet et al., 1984; Taylor and McLennan, 1981]. The REE patterns of the mesosomes are similar in all samples and are characterized by a slightly negative Eu anomaly and moderate light REE (LREE) enrichment $\left((\mathrm{La} / \mathrm{Lu})_{\mathrm{n}}=12-16\right)$ (Figure 2$)$.

The three analyzed leucosomes (Table 1) exhibit similar characteristics in terms of major element composition. They have relatively basic compositions for leucosomes $\left(\mathrm{SiO}_{2}<70 \mathrm{wt} \%\right.$, $\mathrm{Fe}_{2} \mathrm{O}_{3} \mathrm{t}$ between 1.6 and 3.7 wt $\%$, and $\mathrm{MgO}$ between 0.5 and $1.1 \mathrm{wt} \%$ ), and a strongly peraluminous character that is mainly related to the low $\mathrm{CaO}$ and $\mathrm{Na}_{2} \mathrm{O}$ contents. In contrast $\mathrm{K}_{2} \mathrm{O}$ contents are high (up to $7 \mathrm{wt} \%$ ) as are LILE contents, especially $\mathrm{Ba}$. Metallic trace elements such as $\mathrm{Cr}$ and $\mathrm{Ni}$ are typically low. High field strength elements (HFSE) like $\mathrm{Zr}$ can be relatively low (sample L-2 has only $48 \mathrm{ppm}$ of $\mathrm{Zr}$ ). The contents of the HFSE in the melts are mainly controlled by the solubility of accessory phases, and this has important consequences in deciphering the mechanism of the melting process as will be discussed in a later section. REE patterns are variable (Figure 2). Although, the LREE exhibit parallel patterns, the heavy REE (HREE) show variable degrees of fractionation. Both positive and negative Eu anomalies can be found. The significance of all these features will be discussed in a later section.

Two other migmatitic pelites have been analyzed (Table 1). One is a finely banded stromatic migmatite that has a composition between that of the mesosomes and leucosomes and so could represent an average composition of the metapelitic protoliths (sample 92196, Table 1). The other one is a typical kinzigitic gneiss (garnet-cordierite gneiss) that closely resembles the mesosomes of the banded migmatites (sample 90961, Table 1). Its chemical characteristics are similar to those already described for the mesosomes of the granulites.

Some other metapelitic material has not been affected by migmatization but has a clear high- $T$ paragenesis $(\mathrm{Grt}+\mathrm{Crd}+\mathrm{Kfs}+\mathrm{Sil}+\mathrm{Sp})$. Paragneisses from Villanueva de Bogas (samples 92194 and 92199, Table 1) show higher $\mathrm{K}_{2} \mathrm{O}, \mathrm{CaO}$, and $\mathrm{Ba}$ concentrations when compared with migmatitic pelites and also unusually low $\mathrm{Fe}_{2} \mathrm{O}_{3}$ contents (Figure 3). The Fuente Topino paragneiss (sample 92566, Table 1) has $\mathrm{Na}_{2} \mathrm{O} / \mathrm{K}_{2} \mathrm{O}>1$, in contrast to the other migmatitic pelites. All these paragneisses have lesser amounts of $\mathrm{Zr}, \mathrm{Th}, \mathrm{Cr}, \mathrm{Ni}$ than the other metapelites.
Nevertheless, their REE patterns are similar to the mesosome (Figure 2); this uniformity in REE patterns is typical of Phanerozoic clastic sediments [Schetnetger, 1994; Taylor and McLennan, 1985].

\section{Cervatos Anatectic Leucogranites}

$\mathrm{Al}_{2} \mathrm{O}_{3}, \mathrm{Fe}_{2} \mathrm{O}_{3} \mathrm{t}, \mathrm{MgO}$, and $\mathrm{TiO}_{2}$ for the Cervatos leucogranites show decreasing linear trends with increasing silica content; $\mathrm{CaO}_{2} \mathrm{O}$ and $\mathrm{P}_{2} \mathrm{O}_{5}$ are very low and therefore have a narrow variation (Table 1). They show more variability in $\mathrm{Na}_{2} \mathrm{O}$ and $\mathrm{K}_{2} \mathrm{O}$ and have lower $\mathrm{K}_{2} \mathrm{O}$ and LILE (specially $\mathrm{Ba}$ and $\mathrm{Sr}$ ) contents than the migmatitic leucosomes. HFSE in the leucogranites are very low but comparable to those of the migmatitic leucosomes. The REE patterns show two outstanding features (Figure 2): first, the presence of positive or no Eu anomalies in several samples, and second the inverse correlation of the total REE contents with increasing silica [Barbero, 1992]. The strongly fractionated HREE patterns of several leucogranites are very similar to those of the migmatitic leucosomes.

\section{Layos Restite-Rich Granites}

A detailed discussion of the petrography, mineral chemistry and petrogenesis of these granitoids is given by Barbero and Villaseca [1992] and Barbero [1992]. These granites plot in the quartz rich fields of the modal QAP diagram [Barbero and Villaseca, 1992, Figure 3]. They contain a high proportion of cordierite (up to $30 \%$ ) and are strongly peraluminous with the normative corundum values ranging from 4 to $10 \%$ and varying inversely with the silica content. The Layos granites are very high in $\mathrm{Fe}, \mathrm{Mg}$, Ti (in several cases, $\mathrm{Fe}_{2} \mathrm{O}_{3} \mathrm{t}+\mathrm{MgO}+\mathrm{TiO}_{2}>10$ wt $\%)$ reflecting the high modal proportion of cordierite. $\mathrm{CaO}$ is very low, and therefore it has only a narrow variation throughout the series, which precludes the observed geochemical variation being due to igneous fractionation processes involving plagioclase [Barbero and Villaseca, 1992]. $\mathrm{Cr}$ and $\mathrm{Ni}$ contents are high in accord with the high $\mathrm{Fe}, \mathrm{Mg}$, and $\mathrm{Ti}$; trace elements show poorly well-defined trends, although $\mathrm{Ba}, \mathrm{Rb}, \mathrm{Sr}$, and $\mathrm{Cr}$ decrease toward the most felsic members. LREE contents are very constant in all the analyzed samples whereas the HREE are more variable; there are ubiquitous negative Eu anomalies. Their REE patterns resemble those of the mesosomes of the metapelitic granulites (Figure 2).

\section{Chemical Relationships}

On the bivariant diagrams of Figure 3, we have plotted the mesosome-leucosome pairs (joined by a tieline), the rest of the metapelitic material of the ACT and also the Layos and Cervatos type granites. It is clear that the Layos granites plot in between the field of the Cervatos leucogranites and the metapelites which supports a common origin for the restite-rich granites and leucogranites from the metapelites of the area. The experimental melting trends from pelitic protoliths obtained by several workers [Vielzeuf and Holloway, 1988; Patiño Douce and Johnston, 1991], for similar P-T- $\mathrm{aH}_{2} \mathrm{O}$ conditions to those estimated in ACT, have the same trend of increasing $\mathrm{Na}_{2} \mathrm{O}$ and $\mathrm{K}_{2} \mathrm{O}$ and decreasing $\mathrm{Fe}_{2} \mathrm{O}_{3} \mathrm{t}, \mathrm{MgO}$ and $\mathrm{Al}_{2} \mathrm{O}_{3}$. The constancy of $\mathrm{CaO}$ in the generated minimum melts supports an origin for the leucogranites by melting of a pelitic protolith. In the light of petrographic, mineralogical, and geochemical data, Barbero and Villaseca [1992] established a model of restite unmixing to explain the chemical variability of the Layos granite. In this model, the acid end-member is represented by the Cervatos type leucogranites 
Table 1. Representative Chemical Composition (Major, Trace, and REE) of the ACT Migmatites, Metapelites, Restite-Rich Granitoids and, Anatectic Leucogranites

\begin{tabular}{|c|c|c|c|c|c|c|c|c|c|c|c|c|}
\hline & \multicolumn{12}{|c|}{ Sample } \\
\hline & 90961 & $\mathrm{M}-1^{\circ}$ & $\mathrm{M}-2^{\circ}$ & M-3 & 92196 & L-2 $2^{\circ}$ & L-3 $3^{\circ}$ & $\mathrm{L}-\mathrm{I}^{\circ}$ & 92566 & 92194 & 92199 & 77758 \\
\hline Rock type & $\begin{array}{l}\text { Migmatite } \\
\text { Mesosome }\end{array}$ & $\begin{array}{l}\text { Migmatite } \\
\text { Mesosome }\end{array}$ & $\begin{array}{l}\text { Migmatite } \\
\text { Mesosome }\end{array}$ & $\begin{array}{l}\text { Migmatite } \\
\text { Mesosome }\end{array}$ & $\begin{array}{r}\text { Banded } \\
\text { Migmatite }\end{array}$ & $\begin{array}{l}\text { Migmatite } \\
\text { Leucosome }\end{array}$ & $\begin{array}{l}\text { Migmatite } \\
\text { Leucosome }\end{array}$ & $\begin{array}{l}\text { Migmatite } \\
\text { Leucosome }\end{array}$ & Metapelite & Metapelite & Metapelite & Metapelite \\
\hline $\mathrm{SiO}_{2}$ & 56.96 & 57.15 & 58.15 & 58.19 & 58.96 & 68.92 & 69.06 & 69.50 & 65.34 & 55.75 & 57.75 & 62.14 \\
\hline $\mathrm{Al}_{2} \mathrm{O}_{3}$ & 20.10 & 20.16 & 20.31 & 19.43 & 20.53 & 16.91 & 15.21 & 14.96 & 15.86 & 18.64 & 18.39 & 19.66 \\
\hline $\mathrm{TiO}_{2}$ & 1.12 & 1.13 & 1.08 & 1.12 & 1.03 & 0.13 & 0.64 & 0.52 & 0.88 & 0.76 & 0.79 & 0.89 \\
\hline $\mathrm{Fe}_{2} \mathrm{O}_{3} \mathrm{t}$ & 10.39 & 9.39 & 8.35 & 8.89 & 7.73 & 1.56 & 3.65 & 2.56 & 6.37 & 7.51 & 7.14 & 7.03 \\
\hline $\mathrm{MnO}$ & 0.08 & 0.08 & 0.06 & 0.08 & 0.05 & 0.01 & 0.02 & 0.01 & 0.07 & 0.06 & 0.02 & 0.08 \\
\hline $\mathrm{MgO}$ & 3.66 & 3.39 & 2.83 & 3.40 & 2.47 & 0.48 & 1.12 & 0.91 & 2.31 & 3.75 & 3.72 & 2.26 \\
\hline $\mathrm{CaO}$ & 1.45 & 1.54 & 1.56 & 1.52 & 0.63 & 1.31 & 1.31 & 0.86 & 1.77 & 2.52 & 0.86 & 0.66 \\
\hline $\mathrm{Na}_{2} \mathrm{O}$ & 1.75 & 1.79 & 2.41 & 1.82 & 1.54 & 2.75 & 1.93 & 1.83 & 3.29 & 1.53 & 1.16 & 1.46 \\
\hline $\mathrm{K}_{2} \mathrm{O}$ & 2.63 & 3.90 & 3.58 & 3.65 & 4.69 & 6.50 & 5.47 & 7.00 & 2.54 & 6.73 & 6.50 & 3.18 \\
\hline $\mathrm{P}_{2} \mathrm{O}_{5}$ & 0.20 & 0.13 & 0.14 & 0.14 & 0.14 & 0.30 & 0.15 & 0.34 & 0.17 & 0.17 & 0.19 & 0.16 \\
\hline LOI & 1.31 & 1.06 & 1.19 & 1.42 & 1.88 & 0.76 & 1.09 & 1.16 & 1.13 & 2.29 & 3.18 & 2.44 \\
\hline Total & 99.65 & 99.72 & 99.66 & 99.66 & 99.65 & 99.62 & 99.65 & 99.64 & 99.73 & 99.71 & 99.70 & 99.41 \\
\hline $\mathrm{Ba}$ & 547 & 762 & 811 & 898 & 962 & 1341 & 1265 & 1174 & 460 & 851 & 753 & 630 \\
\hline $\mathrm{Rb}$ & 112 & 175 & 226 & 142 & 148 & 236 & 162 & 220 & 105 & 174 & 179 & 144 \\
\hline $\mathrm{Sr}$ & 170 & 237 & 275 & 248 & 220 & 276 & 292 & 247 & 196 & 129 & 95 & 157 \\
\hline $\mathrm{Cr}$ & 541 & 145 & 126 & 137 & 124 & 6 & 34 & 25 & 99 & 111 & 106 & nd \\
\hline $\mathrm{Ni}$ & 80 & 57 & 55 & 54 & 44 & 5 & 17 & 10 & 45 & 50 & 50 & 79 \\
\hline Sc & 20 & 17 & 14 & 16 & 11 & 4 & 8 & 3 & 17 & 17 & 14 & nd \\
\hline V & 143 & 139 & 126 & 139 & 119 & 14 & 37 & 37 & 106 & 124 & 111 & nd \\
\hline $\mathrm{Ga}$ & 26 & 31 & 40 & 29 & 35 & 23 & 21 & 18 & 24 & 32 & 32 & nd \\
\hline $\mathrm{Nb}$ & 20 & 21 & 18 & 21 & 21 & 5 & 13 & 9 & 13 & 13 & 12 & nd \\
\hline Th & 16 & 19 & 19 & 23 & 22 & 5 & 27 & 22 & 9 & 11 & 12 & 14 \\
\hline $\mathrm{Y}$ & 35 & 27 & 22 & 25 & 18 & 11 & 14 & 8 & 23 & 24 & 17 & 30 \\
\hline $\mathrm{Zr}$ & 173 & 218 & 240 & 219 & 249 & 48 & 184 & 166 & 205 & 109 & 124 & 141 \\
\hline $\mathrm{La}$ & 61.56 & 69.41 & 63.93 & 67.39 & 62.06 & 23.15 & 69.66 & 50.98 & 35.09 & 38.65 & 41.27 & 47.35 \\
\hline $\mathrm{Ce}$ & 112.64 & 135.75 & 119.15 & 131.76 & 120.83 & 43.79 & 141.29 & 114.57 & 68.49 & 85.70 & 81.67 & 94.98 \\
\hline $\mathrm{Nd}$ & 50.91 & 54.80 & 53.81 & 54.17 & 56.04 & 21.50 & 57.97 & 51.31 & 33.09 & 32.33 & 36.12 & 38.87 \\
\hline $\mathrm{Sm}$ & 10.30 & 11.05 & 10.56 & 10.88 & 11.66 & 5.34 & 11.30 & 11.87 & 7.35 & 7.02 & 7.91 & 8.27 \\
\hline Eu & 1.76 & 1.93 & 2.08 & 2.09 & 2.06 & 2.21 & 2.57 & 2.06 & 1.82 & 1.56 & 1.62 & 1.92 \\
\hline Gd & 8.23 & 9.03 & 8.54 & 8.24 & 9.14 & 4.62 & 7.87 & 9.65 & 6.51 & 6.18 & 6.76 & 6.68 \\
\hline Dy & 6.95 & 7.07 & 6.06 & 6.37 & 6.03 & 3.36 & 3.86 & 3.95 & 5.62 & 5.62 & 5.11 & 5.72 \\
\hline Er & 3.34 & 3.70 & 2.80 & 3.37 & 2.98 & 1.50 & 2.28 & 1.14 & 3.85 & 3.23 & 3.44 & 3.25 \\
\hline $\mathrm{Yb}$ & 3.14 & 3.30 & 2.36 & 3.03 & 2.78 & 1.27 & 2.22 & 0.51 & 3.43 & 3.14 & 2.49 & 3.07 \\
\hline $\mathrm{Lu}$ & 0.52 & 0.59 & 0.41 & 0.58 & 0.48 & 0.23 & 0.39 & 0.13 & 0.59 & 0.56 & 0.45 & 0.50 \\
\hline
\end{tabular}

LOI, Loss on ignition; nd, not determined

* M-1, M-2, M-3, and L-1, L-2, L-3 are mesosome-leucosome pairs. 
Table 1. (continued)

\begin{tabular}{|c|c|c|c|c|c|c|c|}
\hline & \multicolumn{7}{|c|}{ Sample } \\
\hline & 89103 & 90964 & 89861 & 87196 & 81926 & 93225 & 81925 \\
\hline Rock type & $\begin{array}{l}\text { Layos } \\
\text { granite }\end{array}$ & $\begin{array}{l}\text { Layos } \\
\text { granite }\end{array}$ & $\begin{array}{l}\text { Layos } \\
\text { granite }\end{array}$ & $\begin{array}{r}\text { Cervatos } \\
\text { leucogranite }\end{array}$ & $\begin{array}{r}\text { Cervatos } \\
\text { leucogranite }\end{array}$ & $\begin{array}{r}\text { Cervatos } \\
\text { leucogranite }\end{array}$ & $\begin{array}{r}\text { Cervatos } \\
\text { leucogranite }\end{array}$ \\
\hline $\mathrm{SiO}_{2}$ & 60.50 & 69.53 & 72.52 & 72.09 & 72.16 & 74.18 & 74.36 \\
\hline $\mathrm{Al}_{2} \mathrm{O}_{3}$ & 18.73 & 14.56 & 12.30 & 15.08 & 14.27 & 13.78 & 14.40 \\
\hline $\mathrm{TiO}_{2}$ & 0.59 & 0.51 & 0.66 & 0.12 & 0.59 & 0.13 & 0.06 \\
\hline $\mathrm{Fe}_{2} \mathrm{O}_{3} \mathrm{t}$ & 7.50 & 3.79 & 5.12 & 1.09 & 3.91 & 0.81 & 0.86 \\
\hline $\mathrm{MnO}$ & 0.27 & 0.05 & 0.01 & 0.01 & 0.11 & 0.00 & 0.05 \\
\hline $\mathrm{MgO}$ & 2.68 & 1.14 & 1.23 & 0.13 & 1.08 & 0.25 & 0.40 \\
\hline $\mathrm{CaO}$ & 0.80 & 0.98 & 1.02 & 0.74 & 1.10 & 1.25 & 1.13 \\
\hline $\mathrm{Na}_{2} \mathrm{O}$ & 1.97 & 2.67 & 2.66 & 3.75 & 2.88 & 3.25 & 3.21 \\
\hline $\mathrm{K}_{2} \mathrm{O}$ & 4.05 & 4.65 & 2.77 & 5.19 & 2.71 & 5.34 & 4.21 \\
\hline $\mathrm{P}_{2} \mathrm{O}_{5}$ & 0.28 & 0.32 & 0.36 & 0.17 & 0.15 & 0.16 & 0.22 \\
\hline LOI & 2.34 & 1.53 & 1.10 & 1.11 & 1.21 & 0.64 & 0.82 \\
\hline Total & 99.71 & 99.73 & 99.75 & 99.48 & 100.17 & 99.79 & 99.98 \\
\hline $\mathrm{Ba}$ & 605 & 691 & 258 & 381 & 377 & 573 & 614 \\
\hline $\mathrm{Rb}$ & 98 & 161 & 161 & 156 & 35 & 194 & 77 \\
\hline $\mathrm{Sr}$ & 114 & 171 & 85 & 137 & 148 & 149 & 197 \\
\hline $\mathrm{Cr}$ & 326 & 118 & 262 & 256 & 253 & 5 & 138 \\
\hline $\mathrm{Ni}$ & 63 & 19 & 34 & 56 & 53 & 5 & 41 \\
\hline Sc & 22 & 11 & 14 & nd & nd & 2 & nd \\
\hline V & 111 & 49 & 67 & nd & nd & 12 & nd \\
\hline $\mathrm{Ga}$ & 19 & 17 & 17 & nd & nd & 14 & nd \\
\hline $\mathrm{Nb}$ & 11 & 10 & 15 & nd & nd & 5 & nd \\
\hline Th & 6 & 10 & 8 & 3 & 16 & 10 & 1 \\
\hline Y & 24 & 23 & 10 & 10 & 18 & 5 & 11 \\
\hline $\mathrm{Zr}_{\mathbf{r}}$ & 125 & 170 & 179 & 122 & 177 & 71 & 87 \\
\hline $\mathrm{La}$ & 33.55 & 32.19 & 29.88 & & & 25.25 & \\
\hline $\mathrm{Ce}$ & 64.50 & 62.90 & 59.79 & & & 55.99 & \\
\hline Nd & 29.13 & 30.02 & 28.22 & & & 20.31 & \\
\hline $\mathrm{Sm}$ & 6.53 & 7.15 & 6.19 & & & 3.98 & \\
\hline Eu & 1.25 & 1.37 & 0.90 & & & 1.01 & \\
\hline Gd & 5.43 & 6.64 & 4.99 & & & 3.32 & \\
\hline Dy & 4.54 & 5.11 & 2.94 & & & 1.44 & \\
\hline $\mathrm{Er}$ & 3.05 & 2.76 & 1.26 & & & 0.55 & \\
\hline Yb & 4.25 & 3.29 & 0.97 & & & 0.19 & \\
\hline $\mathrm{Lu}$ & 0.82 & 0.58 & 0.17 & & & 0.07 & \\
\hline
\end{tabular}

and the restitic one by the peraluminous granulites. In this sense, the mesosomes and kinzigitic gneisses have compositions typical of the residues of melting, that is, showing an enrichment in $\mathrm{Fe}$, $\mathrm{Mg}, \mathrm{Ti}$, and other metallic elements ( $\mathrm{Sc}, \mathrm{V}, \mathrm{Cr}, \mathrm{Ni}$ ) (Figure 3). The three leucosome-mesosome pairs follow this kind of trend in the $\mathrm{Al}_{2} \mathrm{O}_{3}-\mathrm{Fe}_{2} \mathrm{O}_{3} \mathrm{t}$ and $\mathrm{MgO}-\mathrm{Fe}_{2} \mathrm{O}_{3} \mathrm{t}$ diagrams (Figure 3) but not in those plots which consider the alkalis and $\mathrm{Ca}$. The enrichment in $\mathrm{K}_{2} \mathrm{O}$ and the relative impoverishment in $\mathrm{Na}_{2} \mathrm{O}$ in the leucosomes together with the enrichment in $\mathrm{CaO}, \mathrm{Na}_{2} \mathrm{O}$, and LILE in the mesosomes point to a separation of plagioclase into the mesosome, which agrees with the fact that the leucosomes are very poor in this mineral and also with the more calcic composition of plagioclase in the mesosomes. This makes the mesosomes depart from simple mixing lines between the metapelites and the anatectic leucogranites. A high abundance of either plagioclase or $\mathrm{K}$-feldspar in leucosomes seems to be a common feature in migmatitic terrains [Ashworth, 1985; Barbey et al., 1990] which has led to the conclusion that most of the leucosomes do not represent anatectic melts but are variably modified by crystal fractionation [Sawyer, 1987] and/or melt loss, which is also a premise for the lack of gamet retrograssion during cooling [Powell and Downes, 1990].

On Figure 4 we have normalized the composition of the mesosomes, leucosomes, Cervatos leucogranites, and Layos restite-rich granitoids to an average metapelite composition. The mesosomes show inverse patterns to those of the leucosomes (Figure 4). Major element mass balance calculations indicate that the mesosomes are the residua after extraction from the metapelites of between $7 \%$ and $14 \%$ of the observed leucogranitic liquids of the ACT. There are marked differences between the leucosomes and the Cervatos leucogranite, the latter being generally poorer in $\mathrm{K}, \mathrm{Rb}, \mathrm{Ba}$, and $\mathrm{Sr}$. This is a consequence of the more $\mathrm{K}$-feldspar rich composition of the leucosomes. With respect to the REE and other trace element contents the mesosomes exhibit a very narrow variation whereas the leucosomes are quite variable. In general, the leucosomes are poorer in REE compared to the average metapelite, and in some cases this is particularly evident in the HREE. La/Lu ratios are always very similar to the associated mesosome. Other trace elements, such as $\mathrm{Y}, \mathrm{Sc}, \mathrm{V}, \mathrm{Cr}$, Ti that are typically partitioned 

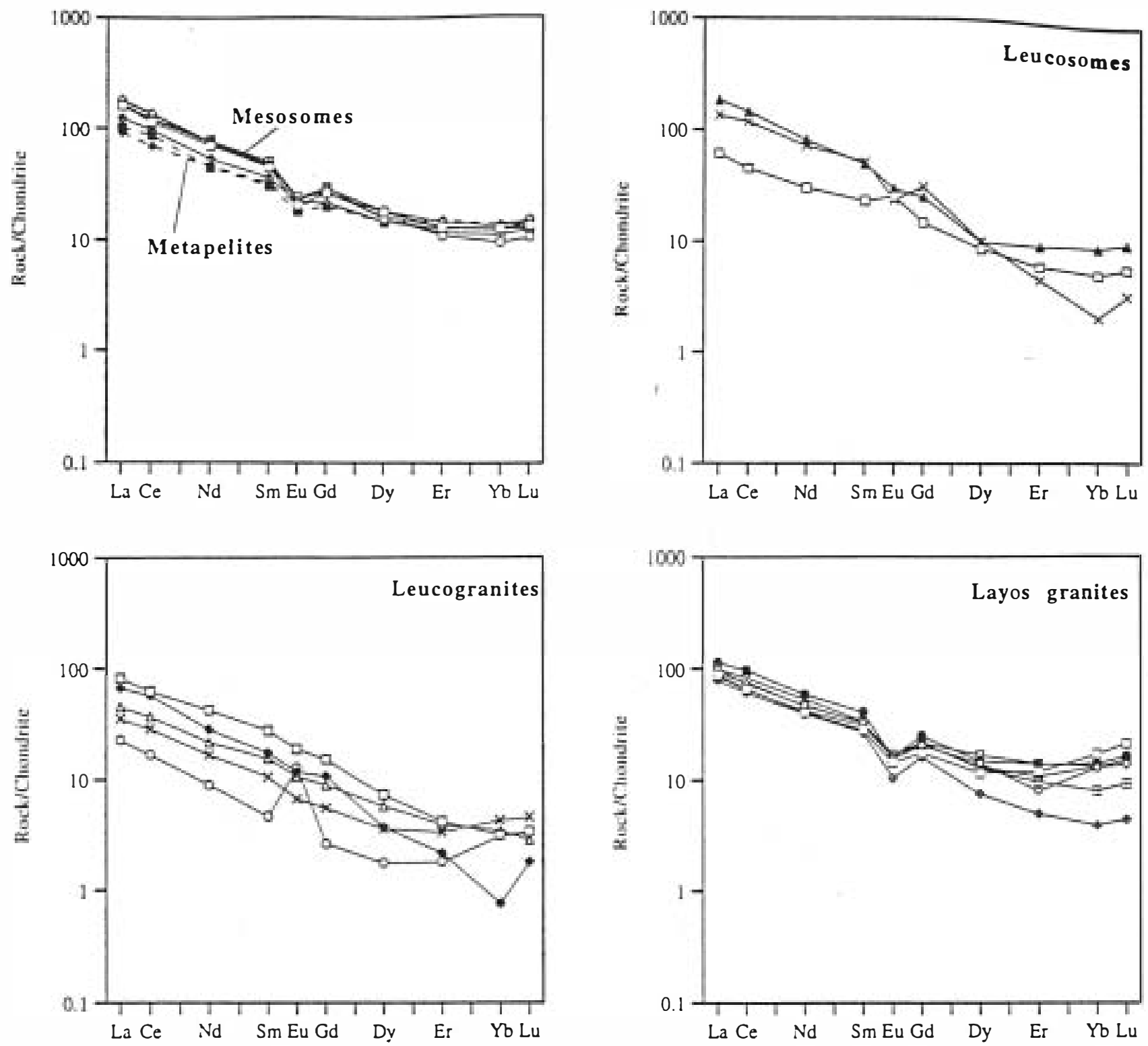

Figure 2. Chondrite normalized REE patterns for the migmatites (mesosomes and leucosomes), metapelites, anatectic leucogranites, and restite-rich granites (Layos type).

into ferromagnesian minerals, are strongly depleted in the leucosomes. $\mathrm{Th}, \mathrm{Zr}$ and LREE contents are more variable in the leucosomes and show similar patterns.

\section{$\mathrm{Sr}$ and Nd Isotopes}

$\mathrm{Sr}$ and $\mathrm{Nd}$ isotope data for all the rock types studied are given in Tables 2 and 3.

\section{Metapelitic Granulitic Migmatites}

As shown in Figure 5 and Table 2, of the three leucosomemesosome pairs considered here, only in one (sample pair M/L-3) do the leucosome and the mesosome show similar $\left({ }^{87} \mathrm{Sr} /{ }^{86} \mathrm{Sr}\right)_{340}$ and $\mathrm{Rb} / \mathrm{Sr}$ ratios, whereas in the other two pairs there are important differences. In the sample pair $\mathrm{M} / \mathrm{L}-2$, the mesosome has a higher $\left({ }^{87} \mathrm{Sr} /{ }^{86} \mathrm{Sr}\right)_{340}$ and a lower $\mathrm{Rb} / \mathrm{Sr}$ than the leucosome (0.71932 and 0.82 compared 0.71727 and 0.86 , respectively), whereas in the M/L-1 pair the leucosome has a slightly higher $\left({ }^{87} \mathrm{Sr} /{ }^{86} \mathrm{Sr}\right)_{340}$ and a higher $\mathrm{Rb} / \mathrm{Sr}$ ratio with respect to the mesosome (0.71782 and 0.89 compared to 0.71720 and 0.24 , Table 2). In contrast, in all three pairs the leucosomes have higher $\varepsilon_{N d}^{34(1)}$ values than the mesosomes, although in L-1 and L-2 leucosomes the ${ }^{147} \mathrm{Sm} /{ }^{144} \mathrm{Nd}$ is much higher compared to the mesosome, whereas in sample M/L-3 the opposite is true (Figure 5). This isotopic disequilibrium suggest that we are dealing with segregated migmatites in which each mesosome does not represent the exact complementary in situ melting residuum to the adjacent leucosome, which implies that segregation at low melt fractions could occur.

Analysis of the kinzigite gneiss gives $\left({ }^{87} \mathrm{Sr} /{ }^{86} \mathrm{Sr}\right)_{340}=0.7203$ and $\varepsilon_{N d}^{340}=-11.7$, comparable to the values of the other mesosomes. The isotopic data of the finely banded migmatite (sample 92196, Tables 2 and 3), which represents a bulk pelite composition of the area, is comparable in $\mathrm{Rb}-\mathrm{Sr}$ systematics to the migmatitic pelites, but shows a slightly higher $\varepsilon_{N d}^{340}$ value (Figure 5). 

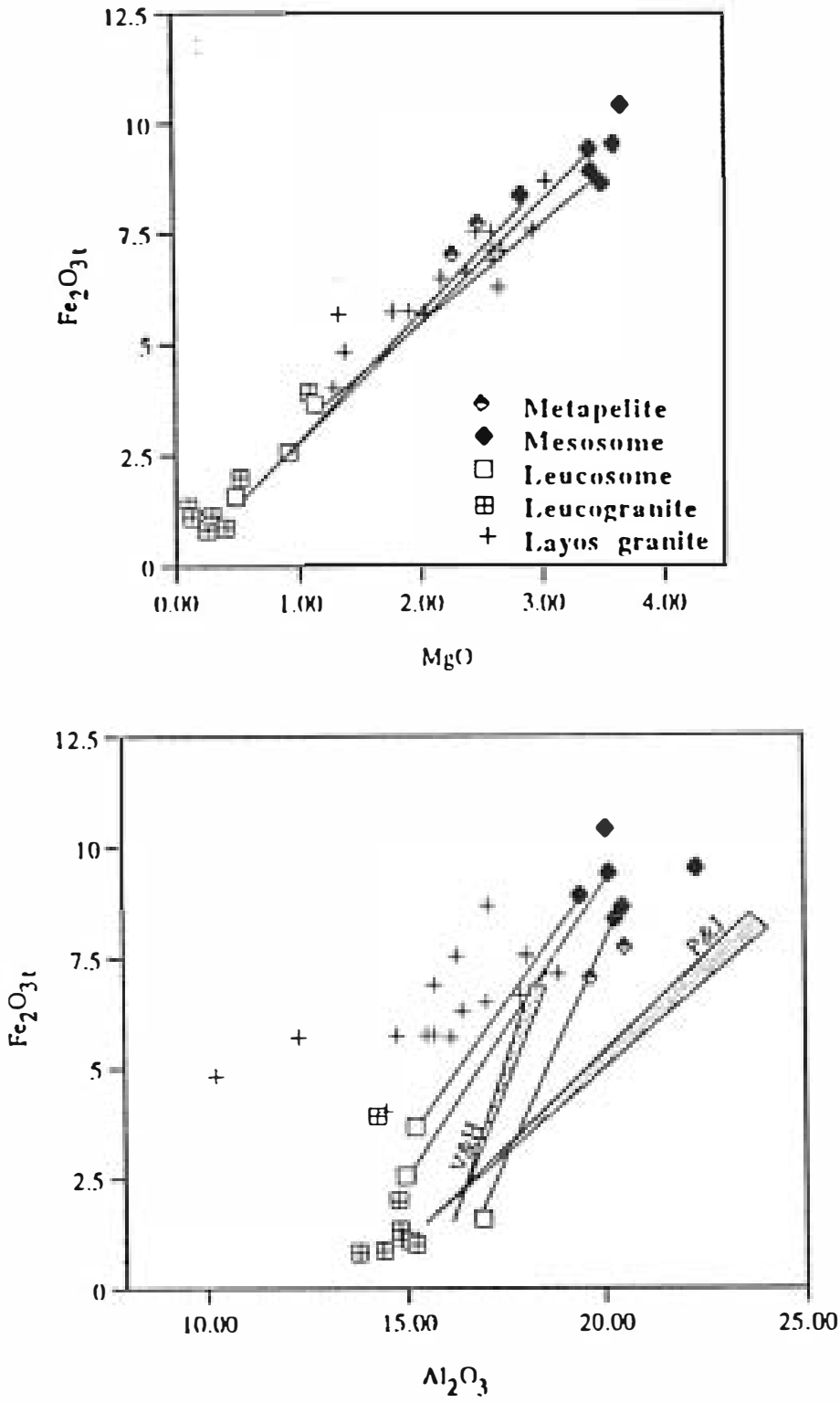
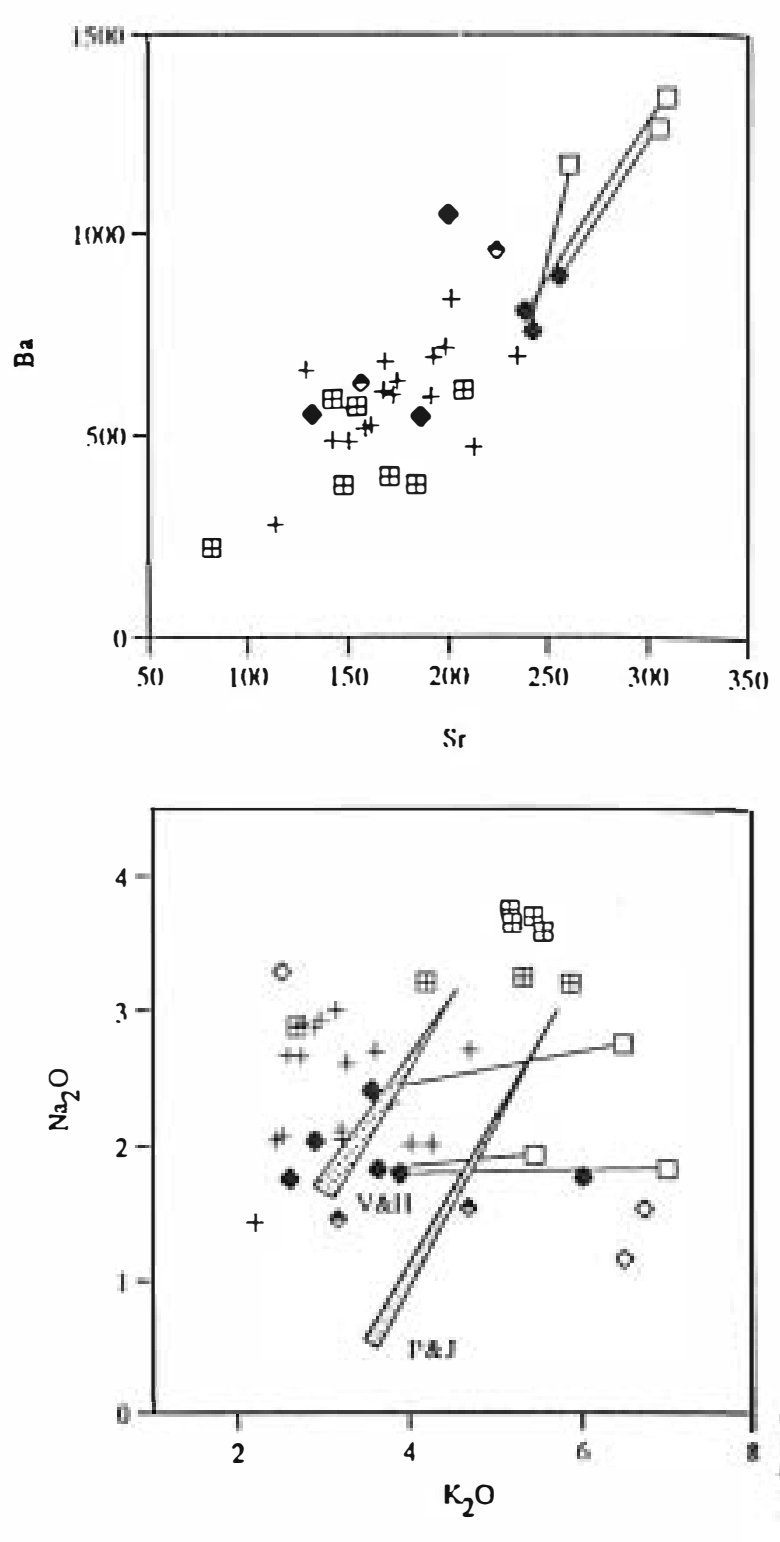

Figure 3. Bivariant plots of several major elements for the migmatites (leucosomes and mesosomes), metapelites, anatectic leucogranites, and restite-rich granites (Layos type). Tie lines join mesosome-leucosome pairs. Shaded areas in $\mathrm{Fe}_{2} \mathrm{O}_{3} \mathrm{t}-\mathrm{Al}_{2} \mathrm{O}_{3}$ and $\mathrm{Na}_{2} \mathrm{O}-\mathrm{K}_{2} \mathrm{O}$ diagrams indicate the trends of melt composition derived from pelitic protoliths of similar composition to those in the ACT' (PJ, Patiño Douce and Johnston [1991] trends; VH, Vielzeuf and Holloway [1988]).

The three metapelites which show no evidence of significant migmatisation have $\left({ }^{87} \mathrm{Sr} /{ }^{86} \mathrm{Sr}\right)_{340}=0.7128-0.7141$ and $\varepsilon{ }_{\mathrm{Nd}}^{340}=-6.0$ to -10.1 , thus defining an isotopically different group when compared with the other migmatitic pelitic granulites (Figure 5). The group composed of the restitic mesosomes shows a narrow variation in $\varepsilon_{N d}^{340}$ and a broader range in $\left({ }^{87} \mathrm{Sr} /{ }^{86} \mathrm{Sr}\right)_{340}$, whereas the unmigmatised group exhibit the reverse features.

When the data for the metapelitic rocks are plotted on a ${ }^{87} \mathrm{Rb} /{ }^{86} \mathrm{Sr}$ versus ${ }^{87} \mathrm{Sr} /{ }^{86} \mathrm{Sr}$ diagram (Figure 6 ) it is apparent that an isochron cannot be defined. The "age" obtained by fitting a line to these data gives a pre-Hercynian value of $515 \mathrm{Ma}$, which suggests that large-scale homogenisation did not occur during the Hercynian orogeny. On the ${ }^{147} \mathrm{Sm} /{ }^{144} \mathrm{Nd}$ versus ${ }^{143} \mathrm{Nd} /{ }^{144} \mathrm{Nd}$ diagram it is also evident that an isochron cannot be defined (Figure 6).

\section{Cervatos Anatectic Leucogranites}

$\mathrm{Sr}$ isotope compositions in the leucogranites show a large variability. $\left({ }^{87} \mathrm{Sr} /{ }^{86} \mathrm{Sr}\right)_{340}$ vary from 0.70982 to 0.71905 , which overlaps with the variations shown by the mesosomes (Figure 5) These may reflect the contribution of different protoliths to the anatectic process, because they cover the field of the metapelites. $\mathrm{Sr}$ isotopic heterogeneity is observed not only on a regional scalt but also within individual leucogranitic massifs, and at a mineral scale. For example, two samples ( 87201 and 93225 ), belonging to the same massif and sampled within few metres of each othe with no apparent contact between them, have $\left({ }^{87} \mathrm{Sr} /{ }^{86} \mathrm{Sr}\right)_{340}$ valued of 0.70982 and 0.71378 . In addition, in the sample STCAT thet are notable differences between garnet and whole rock th $\left({ }^{87} \mathrm{Sr} /{ }^{86} \mathrm{Sr}\right)_{340}(0.71323$ for the whole rock and 0.71097 for the garnet). The variation in $\varepsilon_{N d}^{340}$ is also large $(-3.3$ to -6.8$)$ (Figurg se 

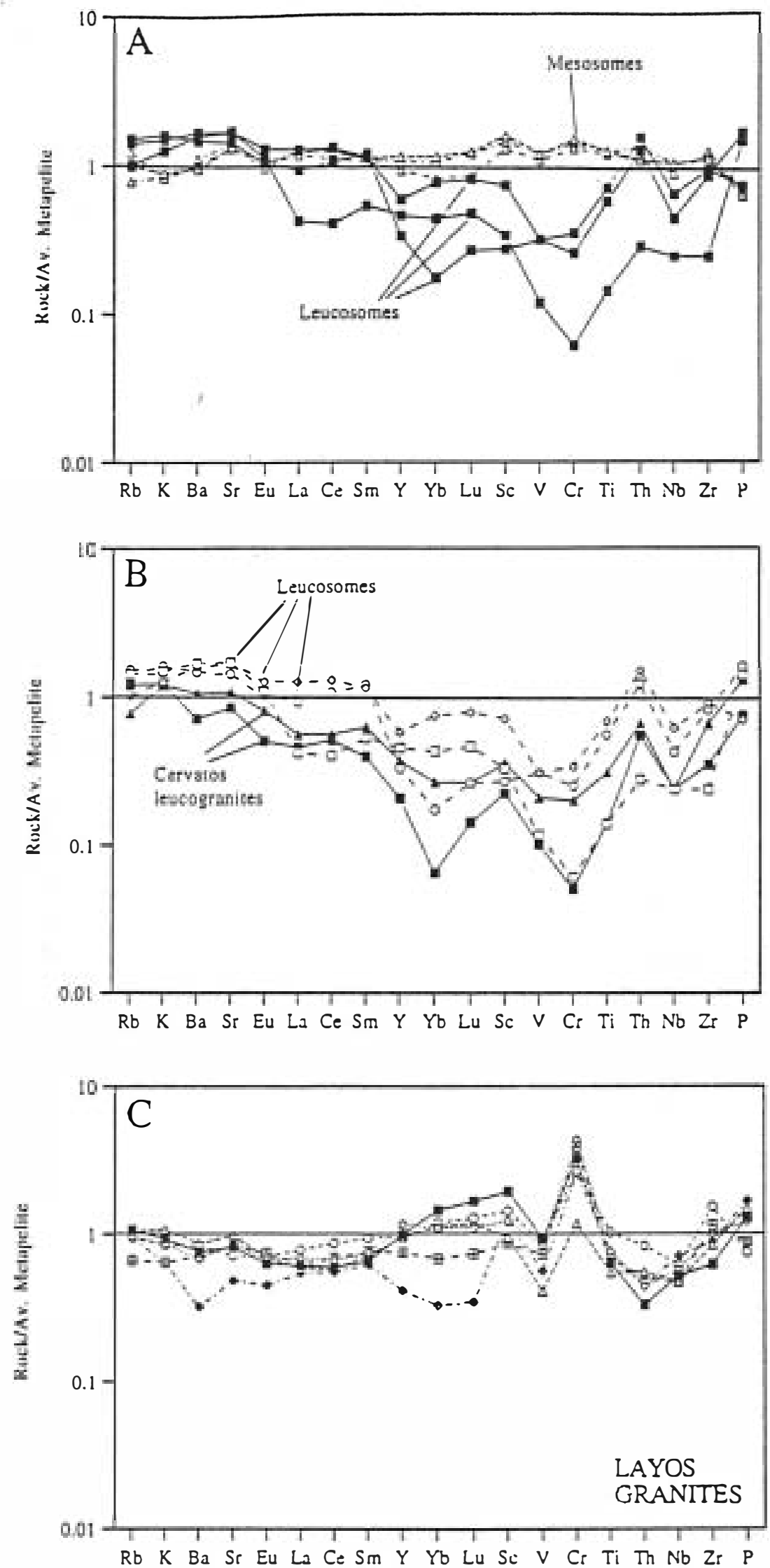

Figure 4. Trace element concentrations normalised to the composition of an average metapelite from the Central Iberian Belt. (a) Migmatites (mesosomes and leucosomes); (b) anatectic leucogranites (Cervatos type) compared with the migmatitic leucosomes; (c) restite-rich granites (Layos type). 
Table 2. Rb-Sr Isotopic Compositions of the ACT Migmatites, Metapelites, Restite-Rich Granites and Anatectic Leucogranites

\begin{tabular}{|c|c|c|c|c|c|c|}
\hline Sample & Rock Type & $\mathrm{Rb}, \mathrm{ppm}$ & Sr, ppm & ${ }^{87} \mathrm{Rb} /{ }^{\beta 6} \mathrm{Sr}$ & $\begin{array}{l}{ }^{87} \mathrm{Sr} /{ }^{\beta 6} \mathrm{Sr} \\
\pm 2 \text { s. e. }\end{array}$ & $\left({ }^{87} \mathrm{Sr} /{ }^{\beta 6} \mathrm{Sr}\right)_{340}$ \\
\hline 90961 & $\begin{array}{l}\text { Migmatite } \\
\text { mesosome }\end{array}$ & 112 & 170 & 1.91 & $0.72952 \pm 3$ & 0.72030 \\
\hline M-1 & $\begin{array}{l}\text { Migmatite } \\
\text { mesosome }\end{array}$ & 175 & 237 & 2.14 & $0.72758 \pm 3$ & 0.71720 \\
\hline L-1 & $\begin{array}{l}\text { Migmatite } \\
\text { leucosome }\end{array}$ & 220 & 247 & 2.59 & $0.73033 \pm 3$ & 0.71782 \\
\hline M-2 & $\begin{array}{l}\text { Migmatite } \\
\text { mesosome }\end{array}$ & 226 & 275 & 2.38 & $0.73084 \pm 3$ & 0.71932 \\
\hline $\mathrm{L}-2$ & $\begin{array}{l}\text { Migmatite } \\
\text { leucosome }\end{array}$ & 236 & 276 & 2.48 & $0.72927 \pm 3$ & 0.71727 \\
\hline$M-3$ & $\begin{array}{l}\text { Migmatite } \\
\text { mesosome }\end{array}$ & 142 & 248 & 1.66 & $0.72600 \pm 2$ & 0.71797 \\
\hline L-3 & $\begin{array}{l}\text { Migmatite } \\
\text { leucosome }\end{array}$ & 162 & 292 & 1.61 & $0.72596 \pm 2$ & 0.71816 \\
\hline 92196 & $\begin{array}{l}\text { Banded } \\
\text { migmatite }\end{array}$ & 148 & 220 & 1.92 & $0.72810 \pm 3$ & 0.71884 \\
\hline 92566 & Metapelite & 105 & 196 & 1.54 & $0.72030 \pm 4$ & 0.71282 \\
\hline 92194 & Metapelite & 174 & 129 & 3.91 & $0.73301 \pm 3$ & 0.71410 \\
\hline 92199 & Metapelite & 179 & 95 & 5.50 & $0.74084 \pm 3$ & 0.71424 \\
\hline 89103 & Layos granite & 98 & 114 & 2.50 & $0.73131 \pm 3$ & 0.71920 \\
\hline 90964 & Layos granite & 161 & 171 & 2.73 & $0.73037 \pm 3$ & 0.71717 \\
\hline 89861 & Layos granite & 161 & 85 & 5.49 & $0.73782 \pm 3$ & 0.71124 \\
\hline 90537 & Layos granite & 154 & 170 & 2.63 & $0.72797 \pm 2$ & 0.71522 \\
\hline 81924 & Layos granite & 108 & 143 & 2.19 & $0.72400 \pm 3$ & 0.71342 \\
\hline M3 & Layos granite & 115 & 139 & 2.40 & $0.72376 \pm 2$ & 0.71212 \\
\hline 87196 & $\begin{array}{l}\text { Cervatos } \\
\text { leucogranite }\end{array}$ & 156 & 137 & 3.31 & $0.73508 \pm 3$ & 0.71905 \\
\hline 81926 & $\begin{array}{l}\text { Cervatos } \\
\text { leucogranite }\end{array}$ & 35 & 148 & 1.20 & $0.72053 \pm 2$ & 0.71473 \\
\hline 93225 & $\begin{array}{l}\text { Cervatos } \\
\text { leucogranite }\end{array}$ & 194 & 149 & 3.76 & $0.72803 \pm 3$ & 0.70982 \\
\hline 81925 & $\begin{array}{l}\text { Cervatos } \\
\text { leucogranite }\end{array}$ & 77 & 197 & 1.13 & $0.71855 \pm 3$ & 0.71307 \\
\hline 87201 & $\begin{array}{l}\text { Cervatos } \\
\text { leucogranite }\end{array}$ & 205 & 100 & 5.98 & $0.74227 \pm 4$ & 0.71378 \\
\hline StCat & $\begin{array}{l}\text { Cervatos } \\
\text { leucogranite }\end{array}$ & 110 & 186 & 1.72 & $0.72153 \pm 2$ & 0.71323 \\
\hline StCat & Garnet & 10 & 5 & 5.70 & $0.73853 \pm 3$ & 0.71010 \\
\hline MA-1 & Argés tonalite & 179 & 280 & 1.85 & $0.71780 \pm 2$ & 0.70885 \\
\hline MA-1 & Gamet & 72 & 11 & 19.18 & $0.83673 \pm 3$ & 0.74390 \\
\hline MA-1 & Monazite & 41 & 159 & 0.75 & $0.71410 \pm 2$ & 0.71056 \\
\hline $\mathrm{MM}-2$ & $\begin{array}{l}\text { Moncloa } \\
\text { granite }\end{array}$ & 112 & 81 & 4.00 & $0.72553 \pm 3$ & 0.70618 \\
\hline MM-2 & Gamet & 67 & 43 & 4.57 & $0.73493 \pm 2$ & 0.71284 \\
\hline MM-2 & Feldspar & 241 & 250 & 2.79 & $0.72326 \pm 2$ & 0.70975 \\
\hline
\end{tabular}

All $\mathrm{Rb}-\mathrm{Sr}$ concentrations were determined by isotope dilution techniques. 
Table 3. Sm-Nd Isotopic Compositions of the ACT Migmatites, Metapelites, Restite-Rich Granites, and Anatectic Leucogranites

\begin{tabular}{|c|c|c|c|c|c|c|c|}
\hline Sample & Rock type & $\mathrm{Sm}, \mathrm{ppm}$ & $\mathrm{Nd}, \mathrm{ppm}$ & ${ }^{147} \mathrm{Sm} / 144 \mathrm{Nd}$ & $\begin{array}{l}{ }^{143} \mathrm{Nd} / 144 \mathrm{Nd} \\
\pm 2 \text { s. e. }\end{array}$ & $\left({ }^{143} \mathrm{Nd} / 144 \mathrm{Nd}\right)_{340}$ & $\underbrace{N d}_{330}$ \\
\hline 90961 & $\begin{array}{l}\text { Migmatite } \\
\text { mesosome }\end{array}$ & 10.30 & 50.91 & 0.122 & $0.511871 \pm 6$ & 0.511599 & -11.7 \\
\hline$M-1$ & $\begin{array}{l}\text { Migmatite } \\
\text { mesosome }\end{array}$ & 11.05 & 54.80 & 0.122 & $0.511878 \pm 7$ & 0.511607 & -11.6 \\
\hline L-1 & $\begin{array}{l}\text { Migmatite } \\
\text { leucosome }\end{array}$ & 11.87 & 51.31 & 0.140 & $0.511979 \pm 7$ & 0.511668 & -10.4 \\
\hline$M-2$ & $\begin{array}{l}\text { Migmatite } \\
\text { mesosome }\end{array}$ & 10.56 & 53.81 & 0.119 & $0.511894 \pm 8$ & 0.511630 & -11.1 \\
\hline $\mathrm{L}-2$ & $\begin{array}{l}\text { Migmatite } \\
\text { leucosome }\end{array}$ & 5.34 & 21.50 & 0.150 & $0.512032 \pm 6$ & 0.511698 & -9.8 \\
\hline M-3 & $\begin{array}{l}\text { Migmatite } \\
\text { mesosome }\end{array}$ & 10.88 & 54.17 & 0.121 & $0.511857 \pm 6$ & 0.511587 & -12.0 \\
\hline $\mathrm{L}-3$ & $\begin{array}{l}\text { Migmatite } \\
\text { leucosome }\end{array}$ & 11.30 & 57.97 & 0.118 & $0.511906 \pm 6$ & 0.511643 & -10.8 \\
\hline 92196 & $\begin{array}{l}\text { Banded } \\
\text { migmatite }\end{array}$ & 11.66 & 56.04 & 0.125 & $0.512032 \pm 7$ & 0.511753 & -8.7 \\
\hline 92566 & Metapelite & 7.35 & 33.09 & 0.134 & $0.512193 \pm 5$ & 0.511894 & -6.0 \\
\hline 92194 & Metapelite & 7.02 & 32.33 & 0.131 & $0.511990 \pm 7$ & 0.511698 & -9.8 \\
\hline 92199 & Metapelite & 7.91 & 36.12 & 0.132 & $0.511979 \pm 6$ & 0.511684 & -10.1 \\
\hline 89103 & Layos granite & 6.53 & 29.13 & 0.135 & $0.512117 \pm 17$ & 0.511815 & -7.6 \\
\hline 90964 & Layos granite & 7.15 & 30.02 & 0.144 & $0.512221 \pm 6$ & 0.511900 & -5.8 \\
\hline 89861 & Layos granite & 6.19 & 28.22 & 0.133 & $0.512288 \pm 9$ & 0.511993 & -4.0 \\
\hline M3WR & Layos granite & 7.76 & 38.43 & 0.122 & $0.512274 \pm 8$ & 0.512002 & -3.8 \\
\hline 87201 & $\begin{array}{l}\text { Cervatos } \\
\text { leucogranite }\end{array}$ & 2.74 & 15.44 & 0.107 & $0.512160 \pm 7$ & 0.511921 & -5.4 \\
\hline 87196 & $\begin{array}{l}\text { Cervatos } \\
\text { leucogranite }\end{array}$ & 3.99 & 19.16 & 0.126 & $0.512029 \pm 6$ & 0.511749 & -8.8 \\
\hline 81926 & $\begin{array}{l}\text { Cervatos } \\
\text { leucogranite }\end{array}$ & 2.86 & 19.74 & 0.088 & $0.512205 \pm 9$ & 0.512010 & -3.7 \\
\hline 93225 & $\begin{array}{l}\text { Cervatos } \\
\text { leucogranite }\end{array}$ & 3.98 & 20.31 & 0.118 & $0.512117 \pm 7$ & 0.511853 & -6.8 \\
\hline 81925 & $\begin{array}{l}\text { Cervatos } \\
\text { leucogranite }\end{array}$ & 0.99 & 6.12 & 0.118 & $0.512250 \pm 9$ & 0.512032 & -3.3 \\
\hline StCat & $\begin{array}{l}\text { Cervatos } \\
\text { leucogranite }\end{array}$ & 7.44 & 39.93 & 0.113 & $0.512218 \pm 5$ & 0.511967 & -4.5 \\
\hline StCat & Gamet & 14.00 & 71.48 & 0.118 & $0.512272 \pm 6$ & 0.512201 & -3.7 \\
\hline MA-1 & Argés tonalite ${ }^{\circ}$ & 14.26 & 67.80 & 0.127 & $0.512183 \pm 7$ & 0.511900 & -5.9 \\
\hline MA-1 & Gamet" & 16.94 & 103.02 & 0.099 & $0.512121 \pm 7$ & 0.511900 & -5.9 \\
\hline MM-2 & $\begin{array}{l}\text { Moncloa } \\
\text { granite }\end{array}$ & 4.64 & 21.77 & 0.104 & $0.512325 \pm 24$ & 0.512093 & -2.1 \\
\hline MM-2 & Felsdpar ${ }^{*}$ & 1.79 & 10.40 & 0.104 & $0.512262 \pm 7$ & 0.512030 & -3.3 \\
\hline MM-2 & Biotite $^{*}$ & 31.19 & 111.92 & 0.168 & $0.512277 \pm 7$ & 0.511902 & -5.8 \\
\hline
\end{tabular}

Uncertainties on epsilon Nd calculation are \pm 0.4 .

- $\mathrm{Sm}-\mathrm{Nd}$ concentrations deternined by isotope dilution techniques. 

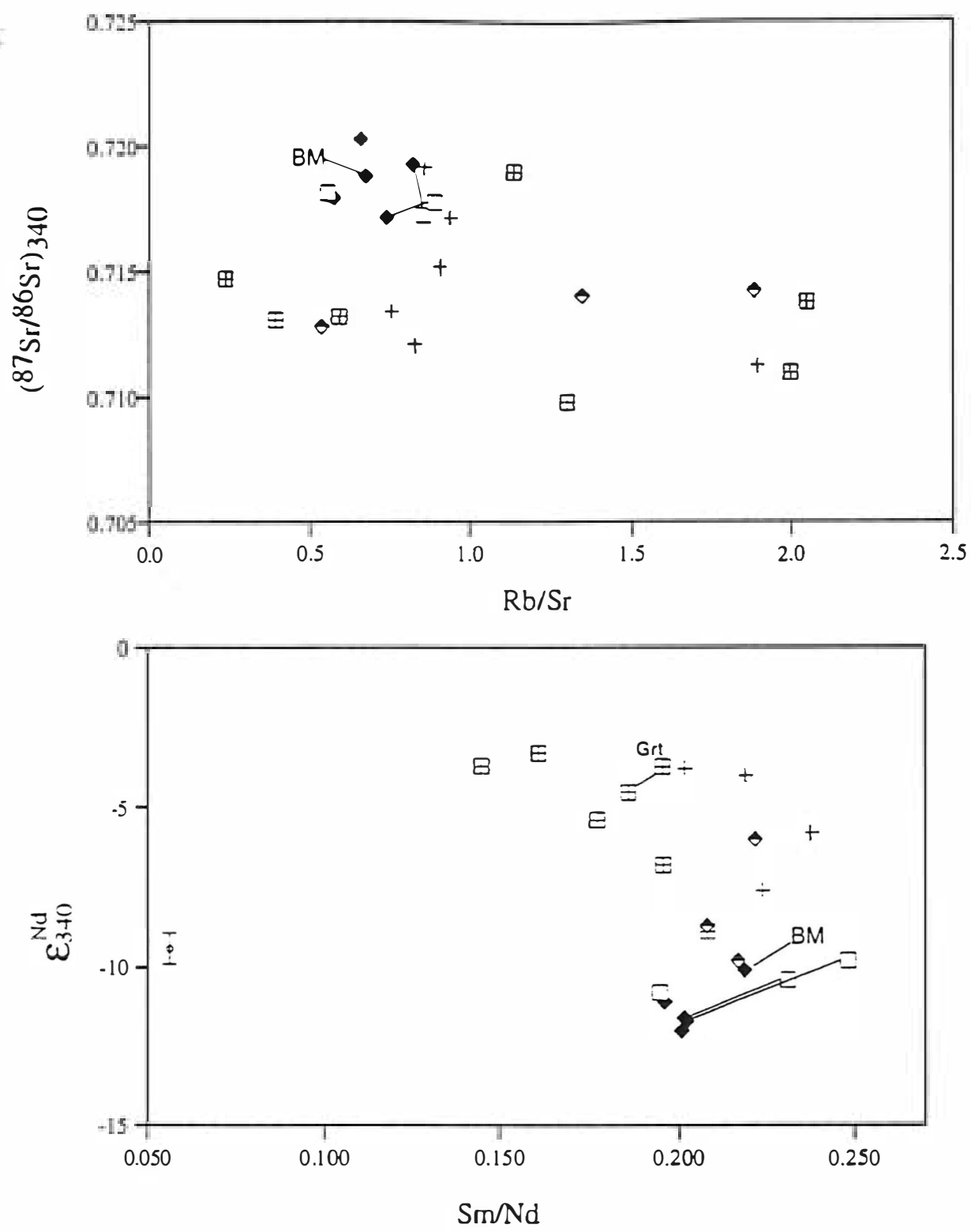

Figure 5. Initial $\mathrm{Sr}$ isotopic ratio at $340 \mathrm{Ma}$ versus $\mathrm{Rb} / \mathrm{Sr}$ ratio and $\varepsilon_{i v}^{340}$ versus $\mathrm{Sm} / \mathrm{Nd}$ ratio diagrams of the $\mathrm{ACT}$. BM, banded migmatite. Symbols as in Figure 3.

and Table 3) which again may reflect the contribution of different protoliths in the anatectic process.

\section{Layos Granite}

The Layos granites are characterised by heterogeneity in $\left({ }^{87} \mathrm{Sr}{ }^{\beta 6} \mathrm{Sr}\right)_{3+4)}$ and $\varepsilon{ }_{\mathrm{N}+\mathrm{i}}^{340}$ ratios $(0.71124-0.71920$ and -4.0 to -7.6 respectively; Tables 2 and 3). Although some of the samples have similar initial $\mathrm{Sr}$ isotopic signature to the migmatitic granulites, others have lower values (Figure 5). In contrast, some clearly have higher $\varepsilon$ ivit and $\mathrm{Sm} / \mathrm{Nd}$ ratios compared to the migmatitic granulites (Figure 5). This tendency to lower $\left({ }^{87} \mathrm{Sr} /{ }^{86} \mathrm{Sr}\right)_{340}$ and higher $\varepsilon_{N d}^{340}$ values in the Layos granites is also shown by the Cervatos type leucogranites, but it is not so marked in the leucosomes which are closer to the estimated protolith composition, represented by the banded migmatite (Figure 5). This feature has also been observed in other anatectic scenarios [Inger and Harris, 1993] where it been used to reject a genetic relationship between the migmatites and the closely related leucogranites, in contrast to the ideas that will be discussed in a later section.

\section{Premetamorphic Peak Granitoids}

$\mathrm{Sr}$ and $\mathrm{Nd}$ isotopic analyses have been performed on whole rocks and mineral separates from premetamorphic peak granitoids: garnet and monazite have been analyzed from the Argés granites, and garnet, plagioclase, monazite, and biotite from the Moncloa type. In the Argés granites (Figure 7a) it is apparent that the mineral separates do not lie along an isochron suggesting small-scale Rb-Sr heterogeneity at least on a scale of $15-20 \mathrm{~cm}$. On Figure $7 \mathrm{~b}$ the gamet and the whole rock give a SmNd age of $340 \mathrm{Ma}$. Even greater heterogeneity is apparent between the mineral separates and whole rock in the Moncloa granites (Figures $7 \mathrm{c}$ and $7 \mathrm{~d}$ ). This small-scale heterogeneity in premetamorphic peak granitoids is unexpected considering that these rocks are clearly affected by a high-T event. One important observation is that some of the mineral fractions are enriched in 

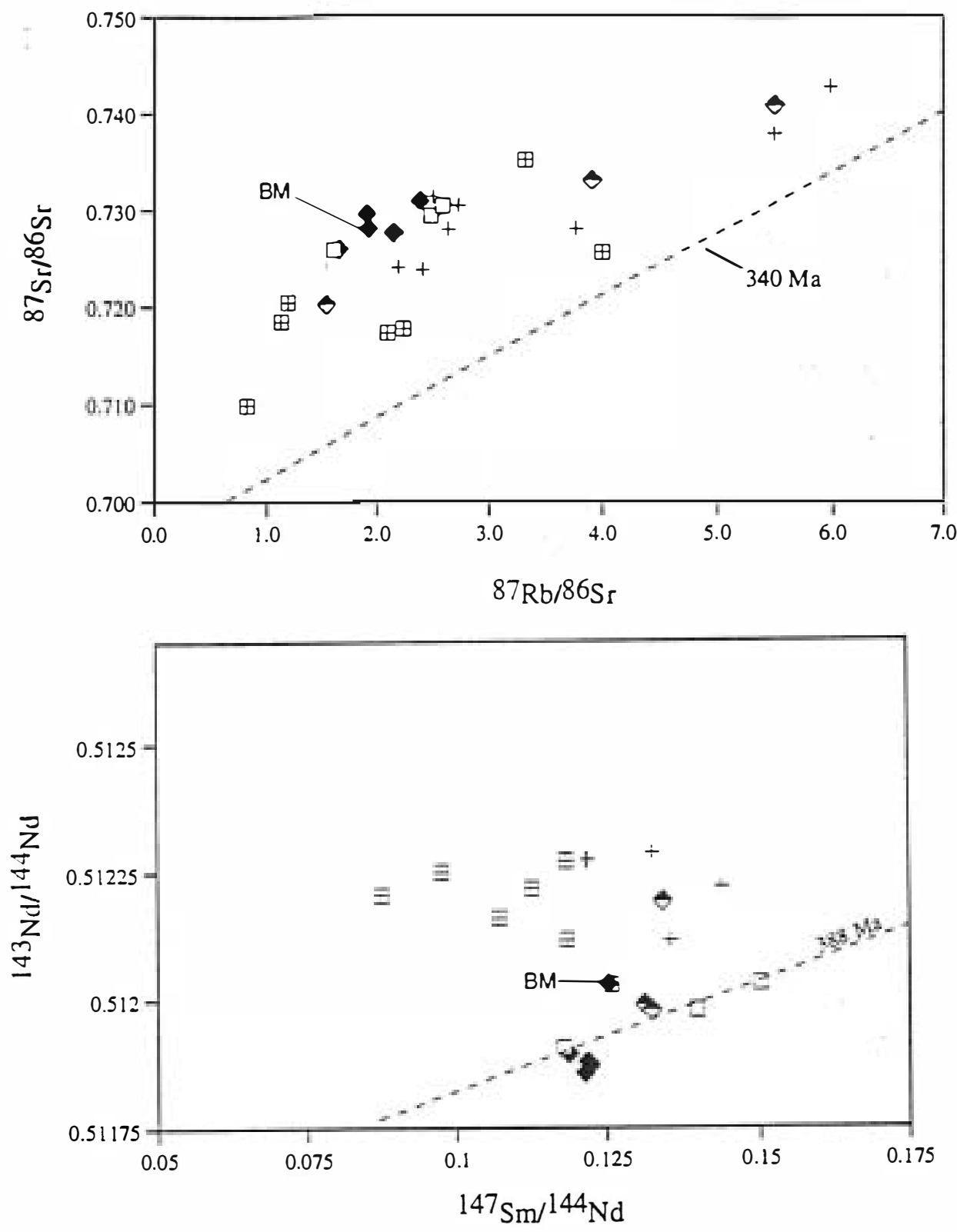

Figure 6. Isochron type plots for Rb-Sr and Sm-Nd isotopes of the studied materials. On the Rb-Sr diagrams a 340 Ma reference line is shown. The $388 \mathrm{Ma}$ line on the Sm-Nd diagram corresponds to the errorchron obtained from the three migmatitic leucosomes. BM, banded migmatite. See text for further explanations. Symbols as in Figure 3.

${ }^{87} \mathrm{Sr} /{ }^{86} \mathrm{Sr}$ (or impoverished in ${ }^{87} \mathrm{Rb} /{ }^{86} \mathrm{Sr}$ ) compared to the whole rock, whereas others show the opposite feature. These data indicate that chemical weathering or fluid-induced disturbance of the system is unlikey to be a possible explanation for the variation as no systematic increase or decrease in the $\mathrm{Rb} / \mathrm{Sr}$ ratio is observed. The detailed petrographic study of the rocks of the ACT reveals that alteration is virtually absent; for example, cordierite is almost always unaltered, usually being blue or colorless crystals of gem quality. Furthermore, late Hercynian magmatism is almost absent (only a few narrow microdioritic dikes $<1 \mathrm{~m}$ thick have been found), and there is no hydrothermal alteration which may have disturbed the isotopic systems (particularly Rb-Sr) ocur.

Two important conclusions may be drawn from these data. First, since the formation of these rocks the diffusion of isotopes must have been severely restricted as there was isotopic heterogeneity on the mineral scale at the time of the granulite facies metamorphism. Therefore the high-T Hercynian metamorphism did not completely destroy any heterogeneities. The preservation of Sm-Nd isotopic heterogeneity in zircons subjected to magmatic temperatures has also been noted by Paterson et al. [1992]. Second, the presence of isotopic heterogeneity on a centimeter scale is on the same scale (centimeters) as that found in the mesosome-leucosome pairs in the migmatites; such a scale is common scale for granulitic terrains [Burton and O'Nions, 1990; McCulloch and Black, 1984].

\section{Disequilibrium Partial Melting}

The study of the petrography and metamorphic reactions in the migmatitic rocks of the ACT reveals fluid-absent biotite melting 

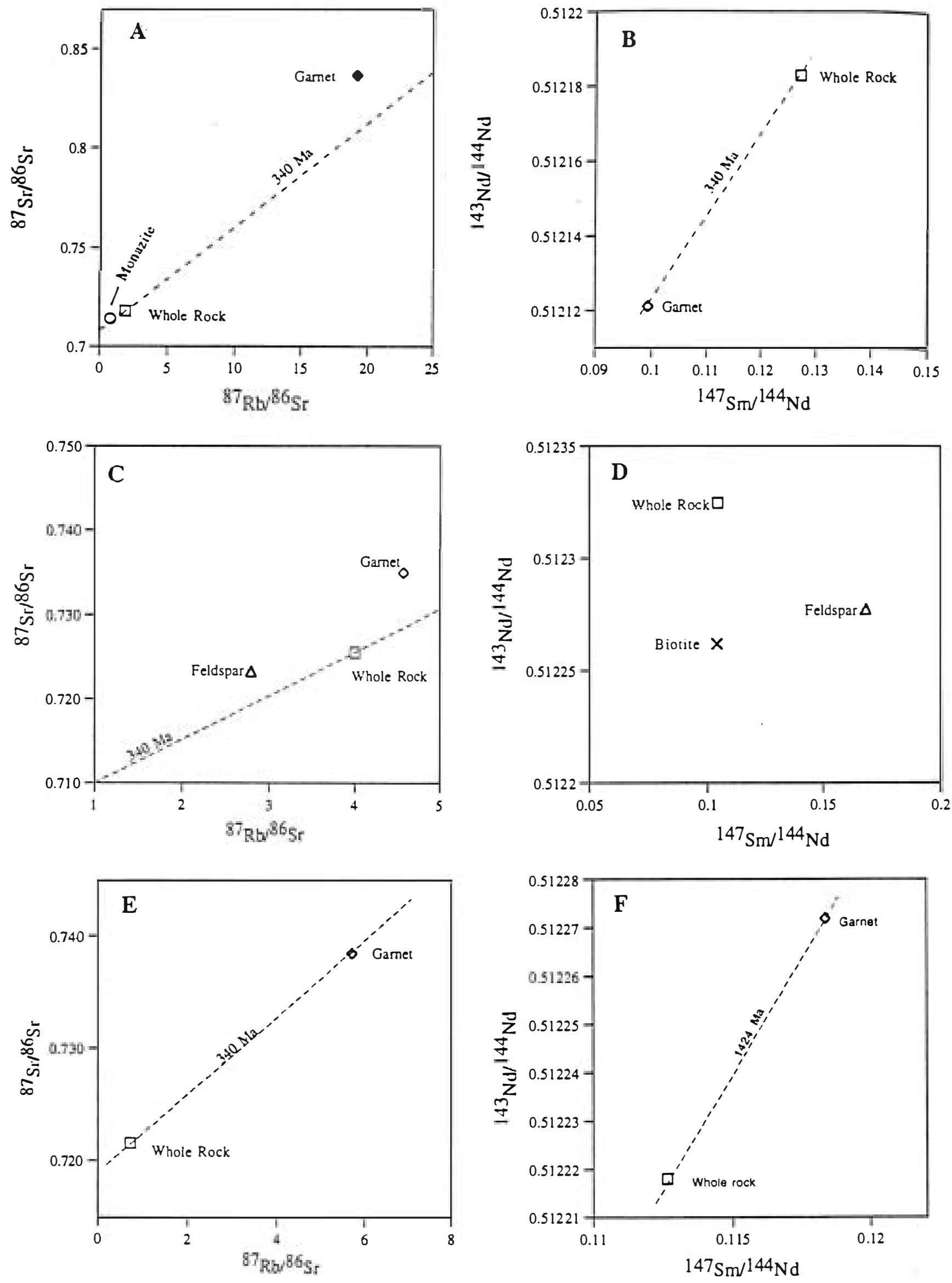

Figure 7. Isochron type plots of the whole rock and mineral separates of the (a) (b) Argés, (c) (d) Moncloa, and (e) (f) Cervatos-type granites. 
as the mechanism that generated the anatectic leucosomes and leucogranites [Barbero, 1995]. From the petrographic relations it is evident that muscovite breakdown reactions leading to melt generation such have been exceeded. The presence of gamet- and cordierite-bearing leucogranites indicates that the melting reaction would have started as

$$
\mathrm{Bt}+\mathrm{Sil}+\mathrm{Qtz}+\mathrm{Pl}=\mathrm{Grt}+\mathrm{Kf} s+\text { melt }
$$

but as pressure decreased it changed to

$$
\mathrm{Bt}+\mathrm{Sil}+\mathrm{Qtz}+\mathrm{Pl}=\mathrm{Grt} / \mathrm{Crd}+\mathrm{Kf} \mathrm{s}+\mathrm{melt}
$$

\section{[Barbero, 1995].}

One possible consequence of incongruent fluid-absent melting is that disequilibrium features may be produced in the resultant melts. As stated by Rubie and Brearly [1990], substantial overstepping of the solidus temperature is required for the new crystalline phase (cordierite or gamet in this case) to nucleate. Then, when melting begins there is an excess of heat available to contribute to the melting. Under such circumstances, the melting rate can be extremely rapid, and this can exert an important influence on the chemistry of the generated liquids and also on their segregation and accumulation. In their consideration of fluid-absent melting of muscovite, Rubie and Brearly [1990] estimated that with an initial overstep of $100^{\circ} \mathrm{C}, 20-50 \%$ of a metapelite could melt within 1 year. Other factors that can control the presence of a significant temperature overstep, such as fluid infiltration in fluid-absent scenarios, or the lack of mutual contact between reactant mineral grains, seem to have been of minor or no importance in the ACT. $\mathrm{aH}_{2} \mathrm{O}$ estimated by Barbero [1995] is low (0.4), and there is no evidence for fluid infiltration, as previously discused. It also seems likely that the initial metapelitic protolith would have been fined-grained (as they are strongly deformed) thus reducing the possibility for a lack of mutual contact between reactant phases.

The chemical characteristics of the migmatitic leucosomes and anatectic leucogranites show that the participation of biotite and $\mathrm{K}$-feldspar in the melting process controls the content of the LILE. The low partitioning of $\mathrm{Sr}$ and Eu between the leucosomes and mesosomes indicates the minor importance of plagioclase in the melting reaction. It has been noted that the typical $\mathrm{K}$-feldspar rich melts produced by vapor-absent melting which have modal proportions of around $50 \% \mathrm{~K}$-feldspar, $30 \%$ quartz and $15 \%$ plagioclase, with only minor amounts of biotite, have REE pattems with positive Eu anomalies [see Barbey et al., 1990; Watt and Harley, 1993]. Moreover, these positive Eu anomalies only occur under disequilibrium melting conditions; equilibrium melting typically gives rise to melts with negative Eu anomalies [Barbey et al., 1989; Harris and Inger, 1992]. Small differences in the amount of accessory phases such as monazite could, however, dramatically change the calculated REE patterns. In fact, there is a variation in the Eu anomaly towards less negative or even positive values with decreasing LREE content, which is typical of increasing amounts of monazite entrained in melts [Watt and Harley, 1993].

The greater increase in $\mathrm{Rb}$ and $\mathrm{K}$ compared to $\mathrm{Ba}$ in the Cervatos leucogranites is a consequence of biotite breakdown under water-undersaturated conditions, and is consistent with a pelitic parentage for these anatectic melts [Harris and Inger, 1992; Inger and Harris, 1993]. REE, Th, Zr, Y, and $\mathrm{P}$ are clearly controlled by accessory mineral phases in several of which they are essential constituents [Harris et al., 1992; Sawyer, 1991; Weber et al., 1985]. Also, there is no correlation between REE, $\mathrm{Zr}, \mathrm{Th}, \mathrm{P}, \mathrm{Y}, \mathrm{Sc}, \mathrm{Cr}$, and $\mathrm{V}$ with the $\mathrm{Fe}-\mathrm{Mg}$ content in the leucosomes, indicating that the accessory phases do not seem to be associated with the mafic phases.

$\mathrm{Zr}, \mathrm{LREE}$, and $\mathrm{P}$ are essential structural constituents (ESC) in zircon, monazite, and apatite respectively. Therefore the concentration of these elements in anatectic melts will be mainly controlled not by trace element partition coefficients but by the solubility of these minerals [Shaw, 1970]. The metapelitic rocks have high enough contents of $\mathrm{Zr}, \mathrm{LREE}$, and $\mathrm{P}$ to saturate a peraluminous melt in accessory phases; typical values are around $200 \mathrm{ppm} \mathrm{Zr,} 270$ ppm LREE (from La to Gd), and 0.21\% $\mathrm{P}_{2} \mathrm{O}_{5}$ (Table 1). Thus, if equilibrium melting occurred, the melt would be saturated in $\mathrm{Zr}, \mathrm{LREE}$, and $\mathrm{P}$. All departures from the saturation values could be explained as a consequence of either disequilibrium melting, especially low values in the melts [Sawyer, 1987] or as restite entrained material [Watt and Harley, 1993]. The amount of dissolved accessory phases under saturated conditions can be evaluated using empirical equations that take into account the temperature effect upon solubilities of the accessory phases in peraluminous and silica-rich melts (usually with $\mathrm{M}=(\mathrm{Na}+\mathrm{K}+2 \mathrm{Ca}) /(\mathrm{AlSi})$ lower than 1.3 and $\mathrm{SiO}_{2}$ around 7073\%) [Watson and Harrison, 1983; Watson, 1987; Harrison and Watson, 1984]. For the conditions of the ACT $\left(T=800^{\circ} \mathrm{C}\right.$ and water-undersaturated conditions), saturation concentrations calculated using the aforementioned equations are $174 \mathrm{ppm}$ for $\mathrm{Zr}, 201 \mathrm{ppm}$ for LREE, and $99 \mathrm{ppm}$ for $\mathrm{P}$, in general much higher than the average contents in the ACT leucogranites.

In general, the solubilities of the accessory phases are enhanced in wet and high-T melts. Watson and Harrison [1983] state that at $\mathrm{H}_{2} \mathrm{O}$ contents above 2 wt $\%$, zircon solubility in melts is independent of the water content, whereas highly undersaturated granitic melts with 0.2 wt $\% \mathrm{H}_{2} \mathrm{O}$ dissolve 30 $40 \%$ less zircon than a water saturated one. Pichavant et al. [1992] found differences of 1 order of magnitude in $P$ diffusion coefficient in apatite between water-saturated $\left(6 \mathrm{wt} \% \mathrm{H}_{2} \mathrm{O}\right)$ and water-undersaturated conditions, although no great change in $\mathrm{P}$ apatite/melt interface concentration was observed between the two experiments. The water content of the ACT anatectic melts is likely to have been high only at the beginning of the melting process, becoming stable at values of around $2-3 w t \% \mathrm{H}_{2} \mathrm{O}$, typical of melts generated by fluid-absent biotite dehydration melting at the conditions estimated in the area [Clemens and Vielzeuf. 1987]. Therefore it seems that the influence of the water content on the solubility of the accessory phases is not very important for the estimated melting conditions in the ACT.

Another factor that exerts an important influence on the solubility of accessory phases is the composition of the melt. If this effect is taken into account in the aforementioned empirical equations for calculating the solubilities of LREE and P [Montel, 1993; Pichavant et al., 1992], the results obtained show that the anatectic granites from the ACT have lower $\mathrm{Zr}$, LREE, and $\mathrm{P}_{2} \mathrm{O}_{5}$ contents than those expected if they were saturated in these elements (Figure 8). This is particularly noticeable in the Cervatos leucogranites and in the leucosomes. In contrast, the restite-rich Layos granite has actual concentrations of $\mathrm{Zr}$ and $\mathrm{LREE}_{\mathrm{t}}$ greater than the calculated saturation concentrations. This is a consequence of the large amount of entrapped restitic material present in these granites, whose geochemistry has been modeled in terms of mixtures of restite and leucogranitic melt [Barbero and Villaseca, 1992]. Although in Figure 8 it is possible to observe a trend in the anatectic granites toward the theoretical 

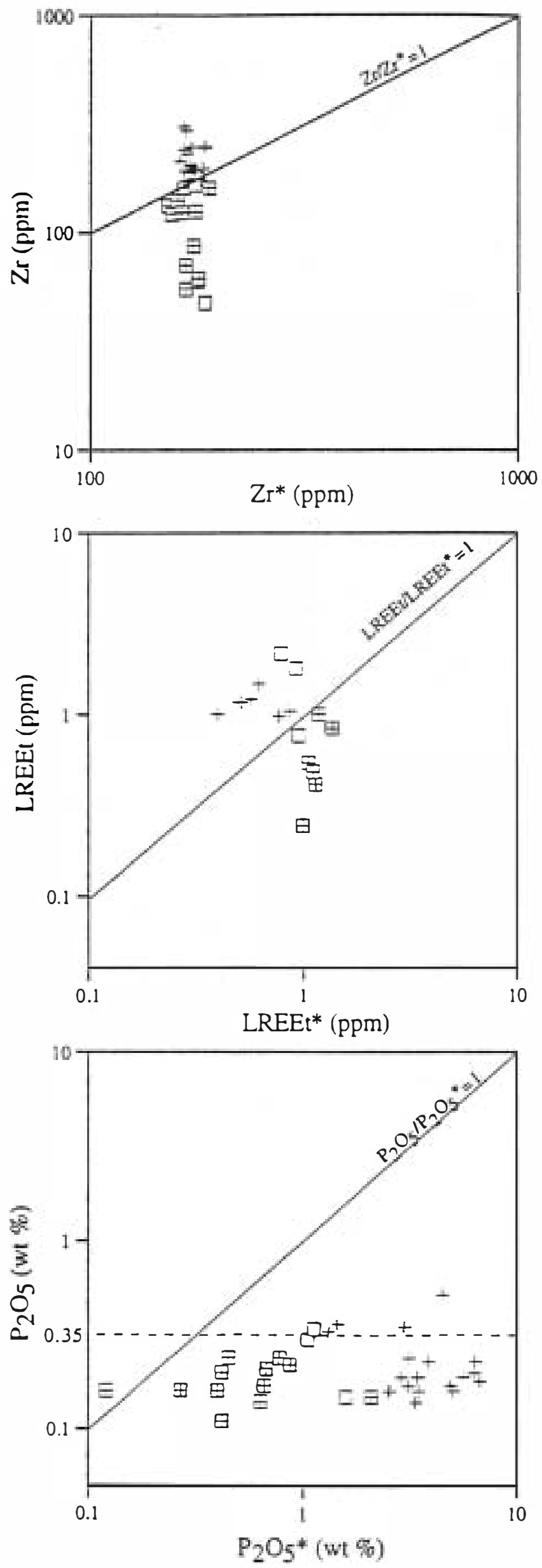

equilibrium values, these cannot be interpreted in terms of equilibrium. This is because it is necessary to take into account the fact that feldspars can make an important contribution to the total LREE budget in granulite facies rocks [Reid, 1990]. Consequently, it is not necessary for monazite to be totally dissolved in order to attain LREE saturation as feldspar can also contribute to the saturation in LREE [Reid, 1990; Harris and Inger, 1992].

The behavior of $\mathrm{P}$ deserves some comments. If the Pichovant et al. [1992] formula is applied, a significant undersaturation in $P$ is observed (Figure 8). This is particularly evident in the strongly peraluminous granites (Layos types), in which the theoretical $\mathrm{P}_{2} \mathrm{O}_{5}$ concentration at the estimated melting temperature would be around $5-7 \%$, which is 20 to 30 times higher than that of the pelitic protoliths. As the Layos granites are a mixture of melt and restite the theoretical $\mathrm{P}$ content calculated is highly overestimated (Figure 8). If we consider that an average leucogranite is representative of the peraluminous melts generated in the area (with $\mathrm{A} / \mathrm{CNK} \approx 1.07$ ) the theoretical $\mathrm{P}$ content at $T=800^{\circ} \mathrm{C}$ would be $0.35-0.40 \%$. However, these contents are still higher than those of the leucogranites.

The departure of the estimated saturation values of $\mathrm{Zr}$, LREE, and $P$ from the measured values in the anatectic granitoids of the ACT points to very efficient extraction of the liquids irrespective of the generated volume, because disequilibrium features are found both in narrow leucosomes and in large leucogranitic massifs. Although, in other anatectic areas, only small-volume melts with limited extraction distances and associated mafic selvedges were found to be depleted in $\mathrm{Zr}$, Th, and LREE relative to their supposed protoliths [Sawyer, 1991], it seems that this is not the general case, as disequilibrium melting is not only influenced by the melting rate but also by the composition of the melt and the mechanism of extraction [Watt and Harley, 1993]. Disequilibrium features may occur when water-undersaturated melts are extracted from their residuum faster than the accessory phases in the protolith can equilibrate with the melt. These factors, together with the limited solubility of the accessory phases in the anatectic melts, suggest that these minerals are concentrated in the residuum after melt extraction. This is consistent with the mesosomes of the granulites being enriched in $\mathrm{Zr}, \mathrm{REE}$, and $\mathrm{Th}$ compared to the original metapelitic protolith (Figure 3) as has also been observed in other areas [Barbey et al., 1989; Watt and Harley, 1993]. Consequently, it appears that in certain lower crustal levels there is a relative enrichment in incompatible heat-producing elements in the residuum after the operation of melting processes under granulite facies conditions .

As mentioned early, several arguments suggest generation of the migmatites and Cervatos leucogranites by disequilibrium partial melting. During disequilibrium partial melting major and trace elements do not attain equilibrium between the melt and the solid residuum. As isotopic equilibration (which is attained by tracer diffusion) is faster than chemical equilibration (which is

Figure 8. Plots of $\mathrm{Zr}$, total LREE, and $\mathrm{P}$ versus their calculated concentrations based on the solubility of the accessory phases under the estimated metamorphic conditions of the $\mathrm{ACT} . \mathrm{Zr} / \mathrm{Zr}{ }^{\circ}=$ $1, \mathrm{LREE}_{\mathrm{l}} / \mathrm{LREE}_{\mathrm{i}}{ }^{*}=1$, and $\mathrm{P} \mathrm{P}^{*}=1$ represent the saturation lines for these three elements. Dashed line on the $P$ versus $P^{\bullet}$ diagram represents the corrected concentrations of $\mathrm{P}$ in order to eliminate the effect of the restitic component in the Layos granites. See text for further explanations. Symbols as in Figure 3. 


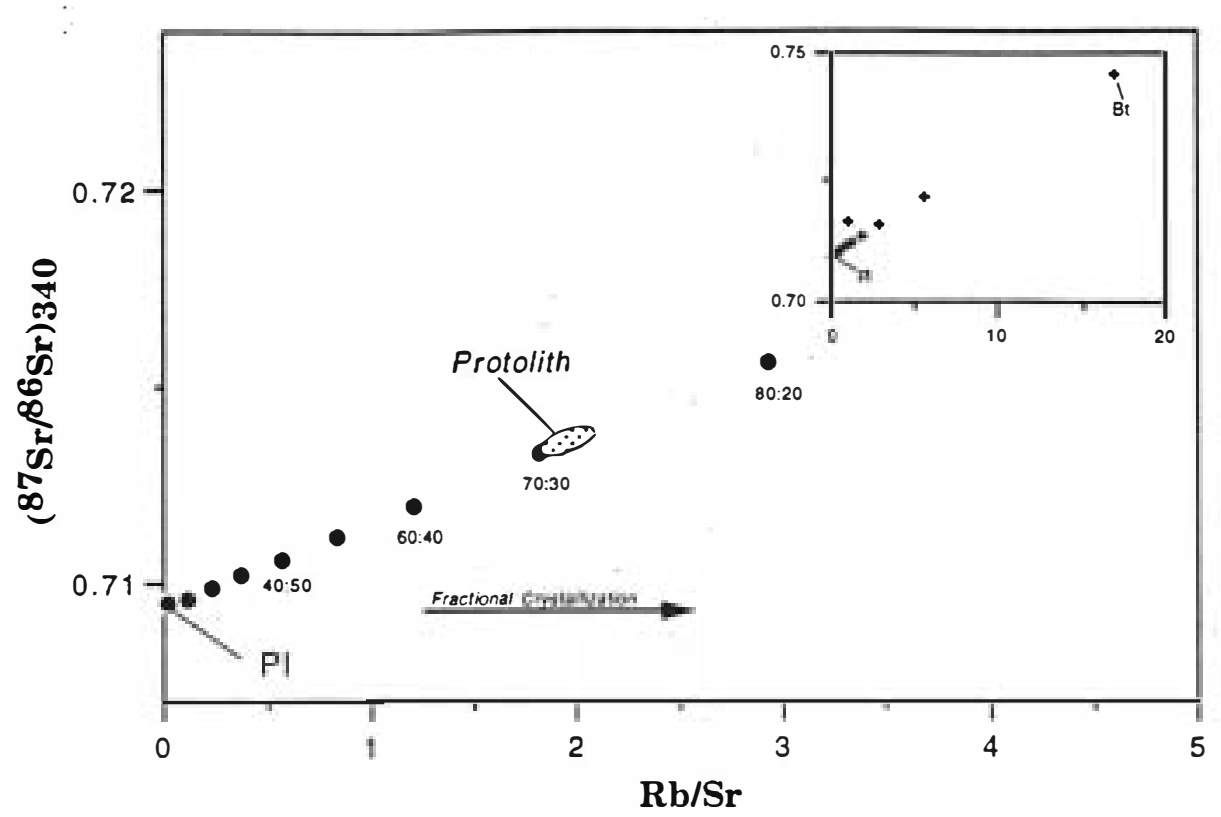

Figure 9. Model showing the shift in $\mathrm{Sr}$ isotopic composition during disequilibrium melting of a pelitic protolith composed of $20 \% \mathrm{Pl}+45 \% \mathrm{Bt}+10 \% \mathrm{Sil}+25 \%$ Qtz. Distribution coefficients for $\mathrm{Sr}$ and $\mathrm{Rb}$ in plagioclase and biotite are those of Arth [1976] for rhyolitic. Assumed values of Sr concentrations in plagioclase and biotite are 400 ppm and $20 \mathrm{pppm}$ respectively, and of $\mathrm{Rb}$ in the same minerals concentrations are $340 \mathrm{ppm}$ and $20 \mathrm{ppm}$, respectively. The ${ }^{87} \mathrm{Sr} /{ }^{86} \mathrm{Sr}$ ratios in plagioclase and biotite assumed for the calculation of the model are 0.7095 and 0.7455 , respectively. Numbers indicate different biotite/plagioclase involment in the melting reaction. See text for further explanations.

attained by chemical diffusion) [Baker, 1989], and given the initial isotopic heterogeneity preserved in the ACT, it appears that anatexis in the ACT occurred under nonequilibrium conditions. Fluid-absent melting of biotite-bearing rocks involves (besides biotite), quartz, plagioclase, and an aluminium silicate, all of which have $\mathrm{Rb} / \mathrm{Sr}$ ratios substantially lower than that of biotite and the whole rock. So, if the reactant phases were closed to significant intergranular exchange of $\mathrm{Sr}$, which could be a consequence of the lack of a fluid phase, the melt could be characterized by a ${ }^{87} \mathrm{Sr} / 86 \mathrm{Sr}$ ratio which was either lower or higher than that of the protolith [Inger and Harris, 1993] depending on the modal proportions of plagioclase and biotite and on their $\mathrm{Sr}$ concentration as shown in modeling below. In the ACT the leucogranites have lower initial ${ }^{87} \mathrm{Sr} / 86 \mathrm{Sr}$ and more variable $\mathrm{Rb} / \mathrm{Sr}$ ratios compared to the protoliths (Figure 5), whereas the restite-rich Layos granites have intermediate values. $\mathrm{Nd}$ isotopes show the inverse behavior: the anatectic leucogranites are richer in radiogenic $\mathrm{Nd}$ and have lower $\mathrm{Sm} / \mathrm{Nd}$ ratios compared to the metapelitic protoliths.

If melting occurs under disequilibrium conditions, we can expect variations not only in the $\mathrm{Rb} / \mathrm{Sr}$ ratios but also in the isotopic ratios of the resultant melts. This can be satisfactorily modeled by calculating the $\mathrm{Rb} / \mathrm{Sr}$ ratio in the generated liquid using the equation for disequilibrium melting given by

$$
C_{\mathrm{L}}=\left[\left(\left(x_{1}+d_{2}^{1} x_{2}+\cdots d_{n}^{i} x_{2}\right) v d_{1}^{i} v\left(x_{1}+d_{2}^{t} x_{2}+\cdots d_{n}^{i} x_{s}\right) d d^{i}\right)\right]
$$

[Allègre and Minster, 1978; Prinzhofer and Allègre, 1985; Barbey et al., 1989; Sawyer, 1991] where $x_{1} \ldots x_{n}$ are the weight proportions of minerals entering the melt, $X_{1} \ldots X_{n}$ are the weight proportions of minerals in the source rock, $d_{n}^{i}$ is the partition coefficient of an element $i$ between mineral $n$ and melt, and $\mathrm{C}_{0}$ is the concentration of the element $i$ in the source rock. The initial $\mathrm{Sr}$ isotopic composition can be calculated considering that the $\mathrm{Rb}-\mathrm{Sr}$ system in these pelitic protoliths is mainly controlled by plagioclase and biotite and hence treating the system as a binary mixture [Faure, 1986]. In this model, several variables such as the modal composition of the protolith and the $\mathrm{Rb}-\mathrm{Sr}$ concentrations and $\mathrm{Sr}$ isotopic composition of the plagioclase and biotite in the source rock have to be assumed. The bulk composition of the source rock can be constrained from the migmatites (see geochemistry section). We have chosen typical values for the modal proportions of minerals in the metapelitic source and for $\mathrm{Sr}$ and $\mathrm{Rb}$ concentrations and for initial ${ }^{87} \mathrm{Sr} /{ }^{86} \mathrm{Sr}$ ratios in biotite and plagioclase (Figure 9); variations in these parameters do not affect to the topology of the calculated model. As the stoichiometry of the biotite dehydration melting reation in terms of optimum bulk composition is $41-36 \%$ $\mathrm{Bt}+23-21 \% \mathrm{Pl}+34-31 \% \mathrm{Qzt}+9-6 \%$ Als [Patiño Douce and Johnston, 1991], the genereted melts will present lower initial ${ }^{87} \mathrm{Sr}{ }^{86} \mathrm{Sr}$ ratio than the protolith. In this respect it is important to note that some recent experimental results indicate that the stoichiometry of the melting reaction and not the bulk composition of the source rock, together with the kinetics of melting are the main factors controlling the $\mathrm{Sr}$ isotopic composition of the melts. So it is possible for source rocks not previously homogenized for $\mathrm{Sr}$ isotopes to produce melts with different $\mathrm{Sr}$ isotopic compositions [Hammouda et al., 1994]. Later fractional crystallization processes could shift the composition of the leucogranites toward different $\mathrm{Rb} / \mathrm{Sr}$ ratios (Figure 9).

$\mathrm{Nd}$ in the ACT anatectic rocks may be controlled not only by garnet and accessory phases, but also by feldspars (Table 3). An 
estimation based on the modal proportions of accessory phases and feldpars in the Moncloa granites suggests that half of the Nd could be contained by feldspars. Therefore, as gamet and feldspar are generated in most of the melting reactions in the area, their incorporation into the melt would produce an increase in $\varepsilon_{N \text { s }}^{344)}$ ratios of the melt (Figure 5). The retention of monazite in the residuum could be responsible for the lower $\mathrm{Nd}$ isotopic ratios [Burton and O'Nions, 1990].

\section{Homogenisation of the Sr-Nd Systems}

\section{During the Melting Process}

There are several well-documented examples which show that although the protoliths maybe isotopically heterogeneous, they may produce homogeneous liquids [e. g., Peucat, 1986; Ferrara et al., 1989]. This suggests that melting is usually an efficient process in producing isotopic homogenization. Nevertheless, as documented in the leucogranites of the ACT, there must be certain scenarios in which partial melting is unable to give rise to isotopically homogeneous melts. The lack of isotopic equilibrium at the mineral level could be a consequence of several different factors:

\section{Time of equilibration}

Isotopic homogenization during anatexis, which occurs by self-diffusion [Baker, 1989], is rapid enough to allow isotopic homogenization of melts and restite [Ferrara et al., 1989; Inger and Harris, 1993] on a meter scale in a geologically reasonable timescale. The main mineral reservoir of $\mathrm{S} r$ in the granitic rocks and migmatites of the ACT is feldspar, with minor amounts in biotite. Feldspar requires a higher temperature than biotite (around $300^{\circ} \mathrm{C}$ ) to equilibrate because of its lower diffusivities [Chermiak and Watson, 1992]. Data indicate that for a reasonable cooling rate of $10^{\circ} \mathrm{C} / \mathrm{Ma}$ and temperatures of $800^{\circ} \mathrm{C}$, only those feldspar crystals with radii smaller than $5 \mathrm{~mm}$ are likely to equilibrate [Cherniak and Watson, 1992]. It seems very unlikely that the large (>5 mm) gamet crystals that appear in several of the anatectic granites of the ACT would have equilibrated during the melting process. This is particularly evident in the case of the leucogranites in which significant $\mathrm{Sr}$ isotopic disequilibrium is shown by the garnets (Figures $7 \mathrm{e}$ and $7 \mathrm{f}$ ). Isotopic disequilibrium between the anatectic graniles and the restitic mesosomes implies that equilibration between $\mathrm{Sr}$-bearing reservoirs (mainly feldspars) occurs less rapidly than the extraction of the melts from their protoliths. It is possible to place semiquantitative constraints on the time required for several metamorphic minerals to equilibrate with a granitic melt based on published diffusion coefficients. Extrapolating the experimental data for diffusion of $\mathrm{Sr}$ in feldspars and apatite [Cherniak and Watson, 1992; Giletti, 1991; Chemiak and Ryerson, 1993] to temperatures appropriate for crustal melting in the ACT (i.e., around $800^{\circ} \mathrm{C}$ ), the diffusion coefficient $(D)$ can be estimated to be around $1 \times 10^{-21} \mathrm{~m}^{2} \mathrm{~s}^{-1}$. This coefficient is not likely to be very different for orthoclase, intermediate plagioclase compositions, and apatite as the calculated closure temperatures for $\mathrm{Sr}$ exchange differ by only $10-15^{\circ} \mathrm{C}$ [Chemiak and Ryerson, 1993]. These data imply that $\mathrm{Sr}$ in the core of minerals with a radius of less than $1-5 \mathrm{~mm}$, the average grain size of the studied migmatitic rocks, will reach equilibrium with a coexisting granitic melt in a period of less than $5 \mathrm{Ma}$. Rates of magma generation, segregation and emplacement in several crustal melting scenarios occur within a period of 2 to $7 \mathrm{Ma}$ [Copeland et al., 1990; Pitcher, 1993].
Nevertheless, in several theoretical studies melting is predicted to occur in a shorter time (0.5 to $1.5 \mathrm{Ma}$ [Patiño Douce et al., 1990]). Consequently, the duration of the melting process, one of the main parameters controlling the isotopic and chemical equilibration between melt and resifuum, needs to be estimated.

It seems that in several migmatitic complexes the segregation of melt is a continuous process which may be related to magma hydraulic fracturing or to deformation-enhanced intergranular flow. Segregation will be favored during vapor-absent melting as this involves a net volume increase, thereby increasing pore fluid pressure. Also, segregation can be enhanced by an extensional tectonic regime. If melting occurs rapidly, the liquids can migrate along fractures induced by volume increase [Mawer et al., 1988]. Wickham [1987] calculated that fluid particle velocity may be as high as $2 \mathrm{~m} \mathrm{y}^{-1}$ which allows substantial melt migration over geological reasonable timescales, providing that the melt can flow as fast as the imposed strain rate [Dell'Angello and Tullis, 1988].

An approximation for the duration of the segregation process can be made on the basis of the diffusivity of $\mathrm{P}$ and $\mathrm{Zr}$ in felsic melts [Sawyer, 1991]. Considering peak temperatures of $800^{\circ} \mathrm{C}$ and water-saturated peraluminous melts with an average water content around 3 wt \% generated by biotite dehydration melting reactions [Clemens and Vielzeuf, 1987], a minimum rate of melt segregation can be estimated based on the solubility of zircon and apatite [Watson and Harrison, 1983; Watson, 1987]. The average sizes of zircon and apatite crystals in metasediments of the ACT are 0.08 and $0.1 \mathrm{~mm}$, respectively. The estimated dissolution time for these grain sizes varies from 5 to 20 years (see also discussion of Sawyer, [1991]) which indicates that melt segregation in the migmatites of the ACT that show disequilibrium features has to be a very rapid process; it is, in effect, instantaneous when compared with the orogenic process.

\section{Heterogeneity of the Source}

The initial isotopic heterogeneity shown by the anatectic granites of the ACT (Cervatos leucogranites, leucosomes, and Layos granites) could be due to reflect heterogeneity of the protoliths. Consequently, different leucogranitic sheets or veins could have different initial isotopic compositions inherited from different levels of the sedimentary pile that has been melted. Nevertheless, this cannot explain the heterogeneity at the mineral scale observed in several cases (Figure 7).

\section{Diffusion coefficients}

It is possible that the diffusion coefficients for several minerals which have low $\mathrm{Sr}$ contents such as garnet and monazite are poorly constrained. However, this is less likely for the feldspars, which are the main Sr-bearing phases, and which therefore control the $\mathrm{Sr}$ isotopic composition, in view of the consistency of the results obtained in several studies [e. g., Cherniak and Watson, 1992; Giletti, 1991].

\section{Evolution of Melts After Segregation}

Rheological studies of anatectic systems have focused their attention on estimating the "critical melt fraction" (CMF) necessary for a magma to move by its own buoyancy. It is important to emphasise that the CMF, which is generally considered to be around 30\% melt [Arzi, 1978], does not represent the lowest melt fraction at which a melt can migrate, as small-degree partial melts may be ef ficiently separated from their 
sources by deformation-enhanced processes rather than through their buoyancy alone [Wickham, 1987]. Several experimental studies [Jurewicz and Watson, 1985; Dell'Angello and Tullis, 1988] have shown that low-melt fractions of granitic composition may form an interconnected fluid network and that the deforming matrix is permeable; thus the melt can be extracted when there is as little as $1-5 \%$ in volume. Furthermore, in several anatectic areas the structure of leucosomes suggests that small volumes of felsic melt, generated by low degrees of partial melting (usually less than 15\%), can segregate because noncoaxial deformation occurs during melting [Tait and Harley, 1988; Sawyer, 1991, 1994]. A n estimation of the degree of partial melting in the ACT can be made from calculations based on the contents of elements which are compatible during crustal melting ( $\mathrm{Ti}, \mathrm{Sc}, \mathrm{V}, \mathrm{Cr}, \mathrm{Ni}$, etc.) using the approximation $F=\left(C_{R S}-C_{n}\right) / C_{R S}$, where $C_{R S}$ is the concentration of an element in the residuum and $C_{6}$ is the concentration of that element in the source [Sawyer, 1991]. The degree of partial melting reached in the ACT is calculated to be $20-40 \%$ which is high enough to generate an interconnected network of melt.

The exact mechanism of melt extraction, although not easy to visualize, must be a continuous pumping of liquids soon after the formation of an interconnected network of melt [Sawyer, 1994]. The continuous generation and segregation of liquid could occur in a similar manner to incremental batch melting; this could explain the high melt percentage deduced above as the composition of the residuum is a consequence of a continuous segregation of low melt fractions. The fact that melt segregation occurs during regional deformation or, at least, under nonhydrostatic conditions is confirmed by the presence of high- $T$ ductile deformation features in several leucosomes; such phenomena are commonly found in leucosomes in extensional ductile shear zones. The high rate of melt segregation estimated in the ACT is comparable with that obtained under extensional conditions ( $3 \mathrm{~mm} \mathrm{y}^{-1}$ to $2 \mathrm{~m} \mathrm{y}^{-1}$; Wickham, [1987]). On the other hand, the presence of restite-rich granites, with up to $60-65 \%$ of trapped restite [Barbero and Villaseca, 1992], indicates not only the overstepping of the CMF but also the formation of crystalliquid mushes which are gravitationally unstable. The gravitational collapse of a melting sector could generate the restite-rich granites that were emplaced in nearby paraautochthonous levels [Barbero, 1992]. These sheets of restite-rich granites do not have the necessary physical characteristics to trigger homogenization processes such as magma convection or mixing. The average viscosity calculated for the peraluminous granites of the area from their chemical composition [Shaw, 1972] is around $10^{6}-10^{7} \mathrm{~Pa}$ s. For a solid content in the melt $(\varnothing)$ of $15 \%$ for the leucogranites and of $50 \%$ for the restite-rich granites the effective viscosity values would be about $3 \times 10^{7} \mathrm{~Pa}$ and $1.7 \times 10^{9} \mathrm{~Pa}$ s respectively. By applying equation (9) of Wickham [1987] these viscosity values imply that the minimum thickness of a granitic sheet that could convect under a low temperature gradient (the liquids and the host rock must not differ significantly in $T$ ) would be hundreds of meters for the leucogranites and several kilometers for the restite-rich types. These values are much higher than the average size of the granitic massifs observed in the ACT, and so it seems unlikely that magmatic processes such as convection could significantly homogenize these magmas.

\section{Discussion and Conclusions}

The peraluminous leucogranites from the ACT may carry a large amount of restitic material which is the product of the incongruent melting reaction, as deduced from their chemical and isotopic disequilibrium features. These granitic types have a limited magmatic evolution because they are close to eutectic compositions, and so, they would rapidly crystallize. Moreover, the rheological characteristics of these crystal-liquid mushes could also contribute to the absence of chemical and isotopic homogenization. The generation of granitic liquids and their subsequent magmatic evolution in the ACT seem to have been very short-lived. Such a melting scenario does not produce a large volume of granitic plutons when compared to other areas. Also the chemical and isotopic peculiarities of this synorogenic magmatism contrast strongly with the characteristics of voluminous late orogenic Hercynian plutonism elsewhere in the Central Iberian Zone.

It is important to note that the most isotopically heterogeneous granites are those derived by low melt fractions in short-lived systems, typical of pure crustal melting scenarios such as the Himalayan leucogranites [Deniel et al., 1987; Castelli and Lombardo, 1988; Inger and Harris, 1992], Trans-Amazonian leucogranites [Cuney et al., 1990], British Columbia leucogranites [Sevigny et al., 1989], Macusani melts [Pichavant et al., 1988] among others. Among the late orogenic intrusions of the Central Iberian Zone, small basic massifs and mafic microgranular enclaves are homogeneously distributed. Several studies reinforce the role of the basic material in the genesis of the late Hercynian plutons, which is in part indicated by isotopic data [Rottura, et al., 1990; Pinarelli, et al., 1992; Moreno Ventas et al., 1994). If the melting mechanism that generated the late magmatism were similar to that determined in the ACT (disequilibrium melting by biotite dehydration reactions), then it would appear that the influx of basic material must enhance the amount of melt produced and hence the ability of that melt to segregate and homogenize, either through additional thermal input, volatile transfer, or both. In this respect, Pitcher [1993, p. 248] states "I believe that the introduction of basaltic magma may well have provided the relatively small amount of extra heat that ensured the full-scale mobilisation leading to pluton emplacement. It is a view confirmed by the presence of microdioritic enclaves which represent evidence of a synchronous and continuing recharge by mafic magmas."

If the amount of generated melt is large enough to permit significant magma accumulation and if the granitic magma interacts with basic material, generating thermal disequilibrium, the possibility of convection and physical mixing is clearly enhanced; thus the generation of voluminous and more isotopically homogeneous plutons is more likely.

Acknowledgments. Isotopic determinations were performed by L.B. during his stay as MEC Postdoctoral Research Fellow at SURRC and St. Andrews University. Anne Kelly and Vincent Gallagher are thanked for their technical support. Detailed reviews of the manuscript by Richard Walker, Nigel Harris, and Michael Brown are gratefully acknowledged. L.B. would like to thank Michael Brown for his invitation to the 1994 AGU Spring Meeting during which part of the conclusions of this work were presented. This work is included in the objectives of and supported by the PB88-0117 and PB93-0295-CO2 DGICYT projects of the MEC (Spain). SURRC is also supported by the Scotrish Universities.

\section{References}

Arth, J. G., Behavior of trace elements during magmatic processes --A summary of theoretical models and their applications, J. Res. U.S. Geol Surv., 4, 41-47, 1976.

Arzi, A. A., Critical phenomena in the rheology of partially melted rocks, Tectonophysics, 44, 173-184, 1978. 
Ashworth, J. R., Migmatites, Blackie, Glasgow, 1985.

Allègre, J. C., and J. F. Minster, Quantitative models of trace element behaviour in magmatic processes, Earth Planet. Sci. Lett., 38, 1-25, 1978.

Baker, D. R., Tracer versus trace element diffusion: diffusional decoupling of $\mathrm{Sr}$ concentration from $\mathrm{Sr}$ isotope composition, Geochim. Cosmochim. Acta, 53, 3015-3023. 1989.

Barbero, L., Plutonismo Sin-orogénico en un Area Granulítica Hercinica: El Complejo Anatéctico de Toledo, Ph.D. thesis, 455 pp., Univ. Complutense, Madrid, 1992.

Barbero, L., Granulite facies metamorphism in the Anatectic Complex of Toledo (Spain): late Hercynian tectonic evolution by crustal extension, J. Geol. Soc. London, 152, in press, 1995.

Barbero, L. and C. Villaseca, The Layos Granite, Hercynian Complex of Toledo (Spain): An example of a parautochthonous restite-rich granite in a granulitic area. Trans. R. Soc. Edinburgh Earth Sci., 83, 127-138, 1992.

Barbero, L., C. Villaseca, and P. Andonaegui, On the origin of the gabbro-tonalite-monzogranite association from Toledo area (Hercynian Iberian Belt), Schweiz. Mineral. Petrogr. Mitt. ,70, 209. 221, 1990.

Barbey, P., J. M. Bertrand, S. Angoua, and D. Dautel, Petrology and $\mathrm{U} / \mathrm{Pb}$ geochronology of the Telohat migmatites, Aleksod, Central Hoggar, Algeria, Contrib. Mineral. Petrol., 101, 207-219, 1989.

Barbey, P., J. Macaudiere, and J. P. Nzenti, High-pressure dehydration melting of metapelites: evidence from the migmatites of Yaounde (Cameroon), J. Petrol., 31, 401-427, 1990.

Bickle, M. J., S. M. Wickham, H. J. Chapman, and H. P. Taylor Jr., A strontium, neodymium and oxygen isotope study of hydrothermal metamorphism and crustal anatexis in the Trois Seigneurs Massif, Pyrennes, France, Contrib. Mineral. Petrol., 100, 399-417, 1988.

Burton, K. W., and R. K. O'Nions, The timescale and mechanism of granulite formation at Kurunegala, Sri Lanka, Contrib. Mineral. Petrol., 106, 66-89, 1990.

Castelli, D., and B. Lombardo, The Gophu La and Western Lunana granites: Miocene muscovite leucogranites of the Bhutan Himalaya, Lithos, 21, 211-225, 1988.

Chemiak, D. J., and F. J. Ryerson, A study of strontium diffusion in apatite using Rutherford backscattering spectroscopy and ion implantation, Geochim. Cosmochim. Acta, 57, 4653-4662, 1993.

Chemiak, D. J., and E B.Watson, A study of strontium diffusion in Kfeldspar, Na-K feldspar, and anorthite using Rutherford backscattering spectroscopy, Earth Planet. Sci. Lett., 113,411-425, 1992.

Clemens, J. D., and D. Vielzeuf, Constraints on melting and magma production in the crust, Earth Planet. Sci. Lett., 86, 287-306, 1987.

Copeland, P., T. M. Harrison, and P. Le For, Age and cooling history of the Manaslu granite: implications for Himalayan tectonics, J. Volcanol. Geotherm. Res., 44, 33-50, 1990.

Cuney, M., P. Sabaté, P. Vidal, M. M. Marinho, and H. Conceicao, The $2 \mathrm{Ga}$ peraluminous magmatism of the Jacobina - Contendas Mirante Belt (Bahia, Brazil): major and trace-element geochemistry and metallogenic potential, J. Volcanol. Geotherm. Res., 44, 123-141, 1990.

Dell'Angelo, L. N., and J. Tullis, Experimental deformation of partially melted granitic aggregates, J. Metamorph. Geol., 6, 495-515, 1988.

Deniel, C., P. Vidal, A. Femández, P. Le For, and J. J. Peucat, Isotopic study of the Manaslu granite (Himalaya, Nepal): inference on the age and source of Himalayan leucogranites, Contrib. Mineral. Petrol., 96 , 78-92, 1987.

England, P. C., and A. B. Thompson, Some thermal and tectonic models for crustal melting in continental collision zones, in Collision Tectonics, edited by M. P. Coward, and A. C. Ries, Geol. Soc.Am. Spec. Pub., 19, 83-94, 1986.

Faure, G., Principles of Isotope Geology. 2nd ed., 589 pp. John Wiley, New York, 1986.

Ferrara, G., R. Petrini, G. Seri, and S. Tonarini, Petrology and isotope geochemistry of San Vincenzo rhyolites (Tuscany, Italy), Bull. Volcanol., 51, 379-388, 1989.

Giletti, B. J., Rubidium and strontium diffusion in feldspars, with implications for cooling histories of rocks, Geochim. Cosmochim. Acta, 55, 1331-1343, 1991

Govindaraju, K., asid G. Nevelle, Fully automated dissolution and separation methods for inductively coupled plasma atomic emission spectrometry rock analysis. Application to the determination of rareearth elements, J. Anal. At. Spectrom., 2,615-621, 1987.

Gromet, L. P., R. F. Dymek, L. A. Haskin, and R. L. Korotev, The "North-American Shale Composite": Its compilation, major and trace element characteristics, Geochim. Cosmochim. Acıa, 48, 2469-2482, 1984.

Hammouda, T., M. Pichavant, and M. Chaussidon, Mechanisms of isotopic equilibration during partial melting: An experimental test of the bevahaviour of Sr, Mineral. Mag., 58A, 368-369,1994.

Harris, N. B. W., and S. Inger, Trace element modelling of pelite-derived granites, Contrib. Mineral. Petrol, 110, 46-56, 1992.

Harris, N. B. W, P. Gravestock, and S. Inger, Ion-microprobe determinations of trace-element concentrations in gamets from anatectic assemblages, Chem. Geol., 100, 41-49, 1992.

Harrison, T. M., and E. B. Watson. The behaviour of apatite during crustal anatexis: equilibrium and kinetic considerations, Geochim. Cosmochimi. Acta, 48, 1467-1477, 1984.

Inger, S., and N. B. W. Harris, Geochemical constraints on leucogranite magmatism in the Langtang valley, Nepal Himalaya, J. Petrol., 34, 345-368, 1993.

Jurewicz, S. R., and E. B. Watson, The distribution of partial melt in a granitic system: The application of liquid phase sintering theory, Geochim. Cosmochim. Acta,49, 1109-1121, 1985.

Mawer, C. K., D. C. Rubie, and A. J. Brearly, A model for rapid melting in crustal shear zones: implications for mechanisms of melt migration, Eos. Trans. AGU, 69, 1411, 1988.

McCulloch, M. T., and L. P. Black, Sm-Nd isotope systematics of Eriderby Land granulites and evidence for the redistribution of $\mathrm{Sm}$ and Nd during metamorphism, Earth Planet. Sci. Lett., 71, 46-58, 1984.

Montel, J. M., A model for monazite/melt equilibrium and application to the generation of granitic magmas, Chem. Geol., 110, 127-146, 1993.

Moreno Ventas, I., G. Rogers, and A. Castro, The role of hybrididation in the genesis of Hercynian granitoids in the Gredos Massif. Spain Inferences from Sr-Nd isotopes. Contrib. Mineral. Petrol., in press, 1994.

O'Nions, R. K., P. J. Hamilton, and N. M. Evensen, Variations in ${ }^{143} \mathrm{Nd} /{ }^{144} \mathrm{Nd}$ and ${ }^{87} \mathrm{Sr} /{ }^{86} \mathrm{Sr}$ ratios in oceanic basalts, Earth Planet. Sci. Lett., 34, 13-22, 1977.

Paterson, B. A., G. Rogers, G., and W. E. Stephens, Evidence for inherited Sm-Nd isotopes in granitoid zircons, Contrib. Mineral. Petrol., 111, 378-390, 1992.

Patiño Douce, A. E., and A. D. Johnston, Phase equilibria and melt productivity in the pelitic system: Implications for the origin of peraluminous granitoids and aluminous granulites, Contrib. Mineral. Petrol., 107, 202-218, 1991.

Patiño Douce, A. E., E. D. Humplureys, and A. D. Johnston, Anatexis and metamorphism in tectonically thickened crust exemplified by the Sevier hinterland, western North America, Earth Planet. Sci. Lett., 97, 290-315, 1990.

Peucat, J. J., Behaviour of Rb-Sr whole rock and U-Pb zircon systems during partial melting as shown in migmatite gneisses from the St. Malo Massif, NE Brittany, France, J. Geol..Soc. London, 143, 875 885, 1986.

Pichavant, M., D. J. Kontak, L. Briqueu, J. Valencia Herrera, and A. H. Clark, The Miocene-Pliocene Macusani volcanics, SE Peru II Geochemistry and origin of a felsic peraluminous magma, Contrib. Mineral. Petrol., 100, 325-338, 1988.

Pichavant, M., J. M. Montel, and L. R. Richard, Apatite solubility in peraluminous liquids: Experimental data and an extension of the Harrison-Watson model, Geochim. Cosmochim. Acta, 56, 3855-3861, 1992.

Pin, C., and J. L. Duthou, Sources of Hercynian granitoids from French Massif Central: Inferences from Nd-isotopes and consequences for crustal evolution. Chem. Geol., 83, 281-296, 1990.

Pinarelli, L., R. Petrini, and A. Rottura, Mantle-crust interaction in the 
European Hercynides: Isotopic and geochemical evidence from Spanish Central System granites (abstract) Trans.R. Soc. Edinburgh Earth Sci., 83, 496, 1992.

Pitcher, W. S., The Nature and Origin of Granite. Blackie, 321 pp. London, 1993.

Powell, R., and J. Downes, Gamet porphyroblast bearing leucosomes in metapelites: Mechanisms, phase diagrams, and an example from Broken Hill, Australia, High-temperature Metamorphism and Crustal Anateris, edited by J. R. Ashworth and M. Brown, pp. 105-123, Unwin Hyman, Boston, Mass., 1990.

Prinzhofer, A., and C. J. Allègre, Residual peridotites and the mechanisms of partial melting, Earth Planet. Sci. Lett., 74, 251-265, 1985.

Reid, M. R., Ion probe investigation of rare earth element distribution and partial melting of metasedimentary granulites, Granulites and Crustal Evolution, edited by D. Vielzeuf, and P. Vidal, pp. 507-522, Kluwer Academic, Norwell, Mass., 1990.

Rottura, A., G. M. Bargossi, V. Caironi, A. Del Moro, E. Maccartone, P. Macera, A. Paglionico, R. Petrini, G. Piccarreta, G., and G. Poli, Petrogenesis of contrastins Hercynian granitoids from the Calabrian Arc, Southem Italy, Lithos. 24, 97-119, 1990.

Rubie, D.C. and Brearly, A.J., A model for rates of disequilibrium melting during metamorphism, High-temperature Metamorphism and Crustal Anatexis, edited by J. R. Ashworh and M. Brown, pp. 57-86, Unwin Hyman, Boston. Mass., 1990.

San José, M. A., A. P. Pieren, J. F. García Hidaigo, P. Herranz, J. R. Peiáez, and A. Perejón. Centrai Iberian Zone. Anteordovician stratigraphy, Pre-Mesuzoic Geology of Iberia, edited by R. D. Dallmeyer, and E. Martínez García, pp.147-159. Springer-Verlag. New York. 1990.

Sawyer, E. W., The role of partial melting and fractional crystallization in detennining migmatite leucosome compositions, J. Petrol.. 28.445$473,1987$.

Sawyer, E. W., Disequilibrium melting and the rate of melt separation during migmatization of mafic rocks from the Grenville Front. Quebec, J. Petrol., 32, 701-738, 1991.

Sawyer, E. W., Melt segregation and magma mobility in the crust, Eos Trans. AGU, 75 (16). Spring Meeting suppl., 362, 1994.

Schnetger, B., Partial melting during the evolution of the amphibolite- to granulite-facies gneisses of the Ivrea Zone, northem Italy, Chem. Geol., 113.71-101, 1994.

Serrano Pinto, M., C. Cásquet, E. Ibarrola, L. G. Corretge, and M. Portugal Ferreira, Sintese geocronologica dos granitoides do Macico Hesperico, Geologia de los Granitoides y Rocas Asociadas del Macizo Hespérico, edited by F. Bea, A. Camicero, A. J. Gonzalo, M. López Plaza, and M. D. Rodríguez Alonso, np. 69-86, Rueda, Madrid, 1987.

Sevigny, J. H., R. R. Parrish, and E. D. Ghent, Petrogenesis of peraluminous granites, Monashee Mountains, Southeastem Canadian Cordillera, J. Petrol., 30, 557-581, 1989.

Shaw, D.M., Trace element fractionation during anatexis. Geochim. Cosmochim. Acta, 34, 237-243, 1970.

Shaw, H. R., Viscosities of magmatic silicate liquids: An empirical method of prediction, Am. J. Sci., 272, 870-893, 1972.
Tait, R. E. and S. L. Harley, Local processes involved in the generation of migmatites within mafic granulites, Trans. R. Soc. Edinburgh Earth Sci. , 79, 209-222, 1988.

Taylor, S. R. and M. McLennan, The composition and evolution of the continental crust: rare earth element evidence from sedimentary rocks, Philos. Trans. R. Soc. London, A, 301, 381-399, 1981.

Vialette, Y., C. Casquet, J. M. Fuster, E. Ibarrola, M. Navidad, M. Peinado, and C. Villaseca, Orogenic granitic magmatism of preordovician age in the Spanish Central System (S.C.S.) Iberian Hercynian Belt, Terra Cognita, 6, 143, 1986.

Vialette, Y., C. Casquet, J. M. Fuster, E. Ibarrola, M. Navidad, M. Peinado, and C. Villaseca, Geochronological study of orthogneisses from the Sierra de Guadarrama (Spanish Central System), Neues Jahrb. Mineral. Monats., HIO, 465-479, 1987.

Vielzeuf, D. and J. R. Holloway, Experimental determination of the fluid absent melting relations in the pelitic system. Consequences for crustal differentiation, Contrib. Mineral. Petrol., 98, 257-276, 1988.

Villaseca, C., L. Barbero, M. J. Huertas, P. Andonaegui, and F. Bellido, $A$ Cross-Section Through Hercynian Granites of Central Iberian Zone. Excursion Guide, 122 pp., Consejo Superior de Investigaciones Cientificas, Madrid, 1993.

Watson, E. B., The role of accessory minerals in granitoid geochemistry. Paper presented at the Hution Conference on Granites, Edinburgh, 1987

Watson, E. B., and T. M. Harrison, Zircon saturation revisited: Temperature and composition effects in a variety of crustal magma types, Earth Planet. Sci. Letl., 64, 295-304, 1983.

Watt, G. R., and S. L. Harley, Accessory phase controls on the geochemistry of crustal melts and restites produced during waterundersaturated partial melting, Contrib. Mineral. Petrol., 114, 550566, 1993.

Weber, C., P. Barbey, M. Cuney, and H. Martin. Trace element behaviour during migmatization. Evidence for a complex melt-residuum-fluid interaction in the St. Malo migmatitic dome (France), Contrib. Mineral. Petrol., 90, 52-62, 1985.

Wickham, S. M., The segregation and emplacement of granite magmas, $J$. Geol. Soc. London, 144, 281-297, 1987.

Wildberg, H. G. H., L. Bischoff, and A. Baumann, U-Pbages of zircons from meta-igneous and metasedimentary rocks of the Sierra de Guadarrama: implications for the Central Iberian crustal evolution, Contrib. Mineral. Petrol., 103, 253-262, 1989.

L. Barbero and G. Rogers, Isotope Geosciences Unit, Scottish Universities Kejearch and Reactor Centre, East Kilbride, Glasgow G75 0QU, Scotlard. (e-mail: barbero@geologygla.ac.uk; grogers@geology.gla.ac.uk)

P. E. Brown, Department of Geography and Geology, Division of Geology, University of St. Andrews, St. Andrews, Fife KY 16 9ST, Scotland.

(Received August 5, 1994; revised November 28, 1994; accepted January 5, 1995.) 